\title{
Evaluation of Some High-Temperature Platinum Resistance Thermometers
}

\author{
J. P. Evans \\ National Bureau of Standards, Gaithersburg, MD 20899
}

\begin{abstract}
Accepted: July 17, 1984
Two sets of high-temperature platinum resistance thermometers of different design have been tested in the temperature range 0 to $1100^{\circ} \mathrm{C}$. One set was constructed at the National Institute of Metrology, in the People's Republic of China, and the other at the National Bureau of Standards. The results of the tests provide information on long- and short-time thermometer stability, and on other characteristics such as temperature coefficient, immersion, self-heating effect, electrical leakage, and durability. The results also show that the behavior of the two sets is similar enough to allow them to be considered as a single set of thermometers, and that the sets perform as well as, or better than, other sets of thermometers tested earlier. It is expected that this information will aid in the evaluation of the high-temperature platinum resistance thermometer as an interpolating instrument for a practical temperature scale up to the gold point.
\end{abstract}

Key words: electrical guarding; high temperature; immersion; performance; platinum resistance thermometer; practical temperature scale; self-heating effect; stability.

\section{Introduction}

The high-temperature platinum resistance thermometer has long been advocated as a standard interpolating instrument for a practical temperature scale up to the gold point, in place of the standard thermocouple. Acceptance of the resistance thermometer for this purpose is likely to come only when sufficient information is available for careful evaluation of thermometer characteristics and performance as they relate to the definition of a practical temperature scale.

The experiments and results reported here are intended to provide some of the needed information on the behavior of high-temperature resistance thermometers; specifically on the following characteristics:

1) Long-time stability at high temperature

2) Short-time stability upon temperature cycling

3) Temperature coefficient of resistance

4) Immersion characteristics

About the Author: J. P. Evans is a physicist in the Temperature and Pressure Division of NBS' Center for Basic Standards.
5) Heating effect of measuring current

6) Electrical leakage of thermometer supporting parts

7) Thermometer durability

8) Agreement among thermometers of derived temperature values.

Another purpose of this paper is to describe some experimental procedures that have proved useful in evaluating thermometer performance. The procedures require little in the way of apparatus beyond what is needed for routine thermometer measurement, calibration, and conditioning.

A third purpose of this paper is to report on the behavior of two sets of high-temperature platinum resistance thermometers from different sources and of different design. One set was constructed at the National Institute of Metrology (NIM), Beijing, People's Republic of China; the thermometers were lent to the National Bureau of Standards (NBS) for testing. The other set was constructed at the NBS. Both types of thermometers have been described in the literature $[1-6]{ }^{1}{ }^{1}$

'Figures in brackets indicate the literature references at the end of this paper. 


\section{General Methods and Equipment}

The general methods and equipment that were used to test the thermometers also have been described [3]. The descriptions are repeated in the following sections for convenience and completeness; they have been updated, where necessary, to apply to the lower resistance thermometers that were used in the present experiments.

\subsection{Thermometer Heat-treating Furnace}

Thermometers are heat-treated in a vertical annealing furnace capable of reaching $1100{ }^{\circ} \mathrm{C}$. The furnace contains a relatively short cylindrical electrical heater near the center that heats only the resistor and a short section (a few centimeters) of adjacent leads to the selected heating temperature. During heat treatment, the thermometers are inserted into closed-end, silica-glass furnace wells, with the resistors situated in the hottest region of the furnace. The space between the wells and the heater contains only air. Six thermometers can be heated at one time.

The furnace is controlled by a Type B thermocouple $(\mathrm{Pt}-30 \% \mathrm{Rh} / \mathrm{Pt}-6 \% \mathrm{Rh})$, and it is monitored by a Type S thermocouple $(\mathrm{Pt}-10 \% \mathrm{Rh} / \mathrm{Pt})$. A calibrated test thermometer can also be used for monitoring. The control system is capable of maintaining the furnace at a desired temperature within about $2 \mathbf{K}$, and is also capable of controlling furnace cooling at a uniform rate of $80 \mathrm{~K} / \mathrm{h}$.

For heat treatment, the thermometer sheaths are first thoroughly cleaned by appropriate means (e.g., acids or solvents) to remove dirt and fingerprints. The thermometers are then inserted into the furnace described above, which has been set to control at the desired temperature. At the end of the heating period, the control system is set to reduce the furnace temperature at the programmed rate of $80 \mathrm{~K} / \mathrm{h}$ so as to avoid quenching in lattice-site vacancies [7]. When the furnace temperature reaches about $520^{\circ} \mathrm{C}$, the thermometers are removed. This procedure avoids the effects of the platinum oxidation that could occur if thermometers were allowed to cool slowly to room temperature [8].

\subsection{Fixed Points}

The triple point of water is realized in a conventional sealed glass cell. The ice mantle is prepared using a special immersion cooler [9] at least $24 \mathrm{~h}$ before measurements are to be made, and the cell is stored in an ice bath. During use, the ice mantle is free to rotate within the cell, the annulus between the cell well and the thermometer contains an aluminum bushing and water, and the cell is shielded from ambient radiation. When a thermometer is fully immersed in a triple-point cell, the bottom tip of its sheath is about $275 \mathrm{~mm}$ below the surface of the liquid water.

The metal freezing points are also realized in sealed cells. The high-purity metal is contained in a graphite crucible with a re-entrant graphite well, and the graphite is surrounded by a sealed glass envelope. Before the cell is sealed, it is evacuated and filled with enough pure argon to provide a pressure of $1 \mathrm{~atm}$ at the freezing point. The cell is similar to the type 1 cell described by Furukawa [10].

The freezing points of all the cells have been found to be sufficiently constant during a single freeze, and sufficiently reproducible from freeze to freeze, to serve the requirements of thermometer testing. The tin, zinc, and silver cells contain Standard Reference Material metals (SRM 741, 740, and 748, respectively) obtained from the NBS Office of Standard Reference Materials. The materials are known to be of high purity (less than $1 \mathrm{ppm}$ total impurity content), and the freezing points of the tin and zinc cells have been established to be well within $1 \mathrm{mK}$ of the freezing points maintained in the NBS Thermometer Calibration Laboratory. The aluminum cell contains metal obtained from a commercial supplier who reported the impurity content to be less than $1 \mathrm{ppm}$. The gold cell contains a sample used in an earlier cell [11]. From the results of tests conducted with the earlier cell, including a comparison with the freezing point of a sample of known high purity, the freezing point of the present cell is believed to be within about $10 \mathrm{mK}$ of the gold point. All of the cells except the gold cell provide a depth of thermometer immersion, from the top of the liquid metal to the inside bottom of the graphite well, of about $17 \mathrm{~cm}$. The immersion in the gold cell is about $15 \mathrm{~cm}$.

The metal freezing-point cells are heated in vertical electrical furnaces different from the annealing furnace. These furnaces are similar to those described earlier [11], but the present furnaces employ only a single long heating zone, and temperature equalization is achieved with aluminum cylinders or heat pipes. The tin and zinc cells are encased in aluminum cylinders located near the center of the zone; the cylinder walls are about $2 \mathrm{~cm}$ thick. The aluminum, silver, and gold cells are centered in coaxial heat pipes, about $10 \mathrm{~cm}$ o.d., $5 \mathrm{~cm}$ i.d., and $45 \mathrm{~cm}$ long, made of Inconel and containing sodium as the working fluid. The cylinders and heat pipes serve to establish for the cells a uniform temperature environment that is maintained about $1 \mathrm{~K}$ below the freezing point by control systems during freezing.

The metal freezing points are established by induced freezing. Except for tin, the molten metals are allowed 
to cool slowly through the supercooled region until they recalesce. A solid mantle of metal is then induced on the cell well by inserting a cool rod. For tin, the freeze is induced in the supercooled metal by blowing air down the cell well, recalescence being detected by a thermocouple wrapped around the glass envelope.

Test thermometers are first preheated for about $5 \mathrm{~min}$ in the furnace just above the freezing point cell, and then measurements at full thermometer immersion are started after the system has come to thermal equilibrium. Except for special tests, the measurement process takes about $30 \mathrm{~min}$, and at least five thermometers can be tested in a single freeze at the tin, zinc, and aluminum points. The gold and silver are remelted after each thermometer test. After testing at the gold, silver, or aluminum points, thermometers are placed in the annealing furnace, held at a temperature near the fixed point for 30 minutes, and then cooled at the programmed rate to $520^{\circ} \mathrm{C}$ to anneal out lattice site defects. Following this, and also after tin- and zinc-point measurements, the resistance at the triple point of water is determined.

\subsection{Electrical Measurements}

Measurements of thermometer resistance are made with an automatic self-balancing bridge [12], and a computer is used to control the operation of the bridge and record the data. The bridge utilizes square-wave excitation, normally at $30 \mathrm{~Hz}$, though $15 \mathrm{~Hz}$ can be selected. It also has provision for selecting thermometer measuring current of $1,2,4$, or $8 \mathrm{~mA}$ and one of four resistor input channels. It can resolve resistance to less than 1 micro-ohm with a linearity of 1 part in $10^{7}$.

Thermometer resistance is determined from a sequence of measurements of both the thermometer and a relatively stable ( 20 micro-ohm per year drift) 10 -ohm standard resistor located in a temperature-controlled oil bath. When a thermometer, carrying a normal measuring current of $4 \mathrm{~mA}$, has come to thermal equilibrium in a fixed-point cell, 10 readings of its resistance are recorded. The system then switches to the standard resistor and records 10 readings at the same current. Immediately thereafter, the thermometer is reconnected to the bridge and the measuring current is doubled. When the thermometer has come to thermal equilibrium at this higher current (a period of $3 \mathrm{~min}$ is usually allowed), additional sets of 10 readings are recorded for the thermometer and standard resistor. The entire process takes about $7 \mathrm{~min}$. From these data, a mean value of the ratio of thermometer resistance to standard-resistor resistance, extrapolated to zero measuring current, is computed and stored. The computer also calculates the heating effect of the normal measuring current, and the estimated standard deviation of the computed mean ratio value. This standard deviation seldom exceeds the equivalent of 0.2 micro-ohm.

\section{Thermometers}

The thermometers used in the experiments were in some ways similar to other high-temperature platinum resistance thermometers that have been described in recent years $[3,5,11]$. The temperature sensing resistors were 1 to $3 \mathrm{~cm}$ long and about $0.5 \mathrm{~cm}$ in diameter, they were connected to four platinum leads, and they were sealed in long $(70-80 \mathrm{~cm})$ silica-glass tubes. Thermometer resistance at $0^{\circ} \mathrm{C}$ was small-less than $1 \mathrm{ohm}$.

In other ways the thermometers were novel. The resistors in the NIM thermometers were of the singlelayer, bifilar helix design, but the support for the resistor wire consisted of a single notched silica-glass blade, rather than the customary cross. The NBS thermometers employed newly-designed "toroidal" resistors and guarded leads. Detailed features of the thermometers are presented in tables 1 and 2 .

The NIM thermometers had been stabilized by heat treatment, as indicated in table 2, before they were transported to NBS. Properties of the thermometers measured at the NIM during the stabilization are shown in figure 1. Upon their arrival at the NBS the four NIM thermometers were inspected. It was observed that three thermometers $(18227,18236,18237)$ had bent sheaths, and that in two of the thermometers (18227 and

Table 1. General features of thermometers.

\begin{tabular}{lcc}
\hline & NIM & NBS \\
\hline Overall length & & \\
(including header) & $805 \mathrm{~mm}$ & $885 \mathrm{~mm}$ \\
Header length & $85 \mathrm{~mm}$ & $125 \mathrm{~mm}$ \\
External tube length & $720 \mathrm{~mm}$ & $760 \mathrm{~mm}$ \\
Nominal tube diameter & $7 \mathrm{~mm}$ & $7 \mathrm{~mm}$ \\
Header diameter & $20 \mathrm{~mm}$ & $19 \mathrm{~mm}$ \\
Resistor type & Single layer & Toroidal \\
& helix & (straight wire) \\
Resistor former & Notched silica & Notched-end \\
& blade & silica tube \\
Former length & $40 \mathrm{~mm}$ & $15 \mathrm{~mm}$ \\
Resistor coil length & $30 \mathrm{~mm}$ & $10 \mathrm{~mm}$ \\
Resistor wire diameter & $0.4 \mathrm{~mm}$ & $0.25 \mathrm{~mm}$ \\
Nominal resistance & & \\
at $0{ }^{\circ} \mathrm{C}$ & 0.25 ohm & 0.37 ohm \\
Lead insulator type & Silica tube & Long silica tubes \\
& and disk & with internal guard \\
Lead wire diameter & $0.3 \mathrm{~mm}$ & $0.25 \mathrm{~mm}$ \\
Length of roughened & &
\end{tabular}


Table 2. Features of individual thermometers.

\begin{tabular}{|c|c|c|c|c|}
\hline $\begin{array}{l}\text { Thermometer } \\
\text { number }\end{array}$ & $\begin{array}{l}\text { Nominal resistance } \\
\text { at } 0^{\circ} \mathrm{C} \text {, ohm }\end{array}$ & $\begin{array}{l}\text { Initial stabilization, } \\
\mathrm{h} \text { at } 1100^{\circ} \mathrm{C}\end{array}$ & $\begin{array}{l}\text { Alpha coefficient, } \alpha \text {, } \\
\text { at beginning of test, } \\
\times 10^{6}, \mathrm{~K}^{-1}\end{array}$ & $\begin{array}{l}\text { Distance in } \mathrm{mm} \text {, } \\
\text { bottom of former to } \\
\text { bottom of sheath at } \\
\text { room temperature }\end{array}$ \\
\hline \multicolumn{5}{|c|}{ NIM thermometers } \\
\hline 80179 & 0.244 & 350 & 3927.1 & 1.0 \\
\hline 18227 & 0.260 & 350 & 3926.9 & 0.5 \\
\hline 18236 & 0.257 & 350 & 3926.8 & 0 \\
\hline 18237 & 0.263 & 500 & 3926.8 & 1.5 \\
\hline \multicolumn{5}{|c|}{ NBS thermometers } \\
\hline 8202 & 0.373 & 400 & 3926.9 & 7.5 \\
\hline 8204 & 0.361 & 400 & 3927.0 & 7.0 \\
\hline 8205 & 0.378 & 400 & 3926.8 & 7.5 \\
\hline
\end{tabular}

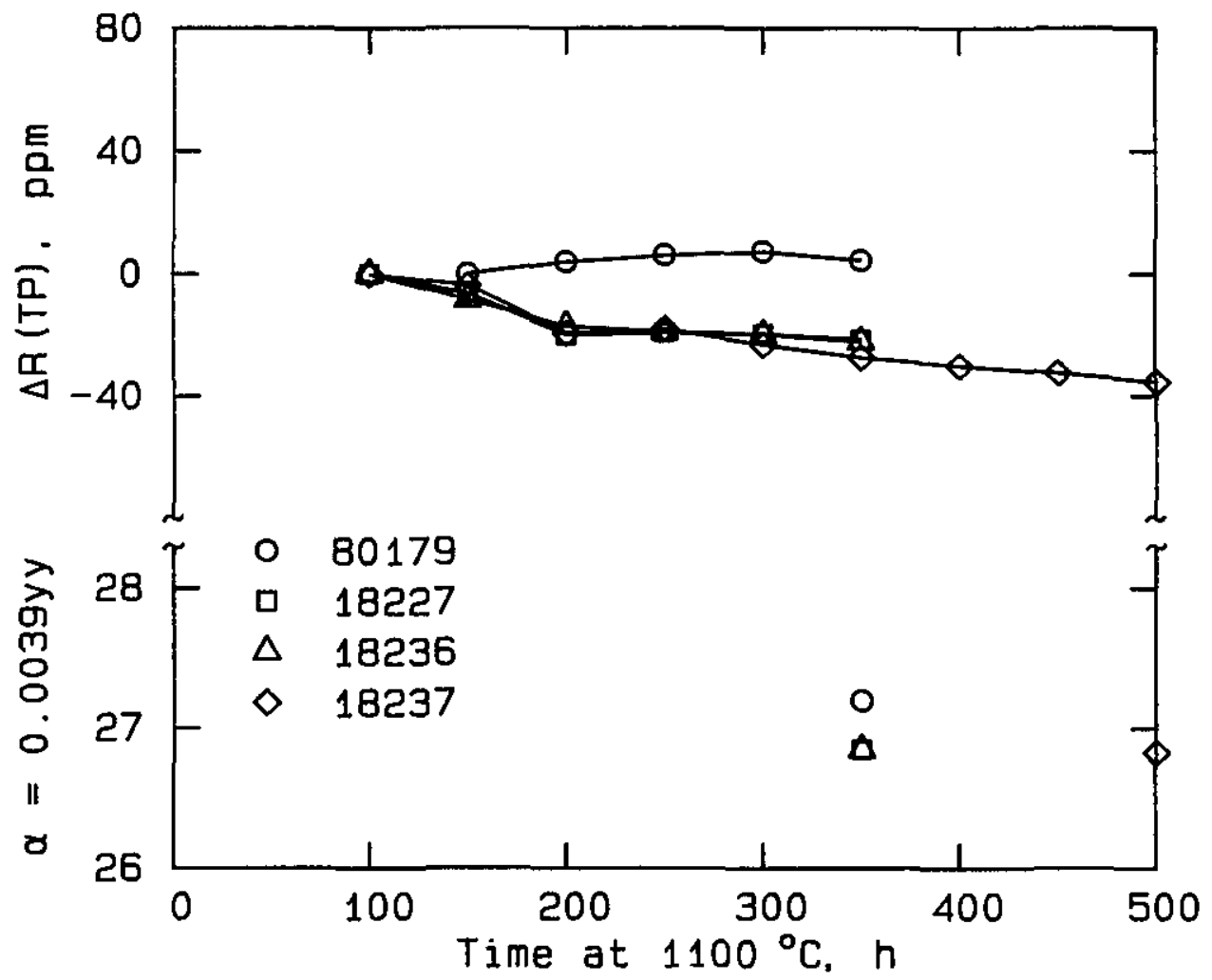

Figure 1-Change in characteristics of NIM thermometers during stabilization. The measurements were made at the National Institute of Metrology, Beijing. Both the relative change in thermometer resistance at the triple point of water (parts in $10^{6}, \mathrm{ppm}$ ) and the alpha coefficient, $\alpha$, are shown.

18236), the resistor support blade was bent. It was believed that these minor defects would not introduce unwanted biases into the experiments, so all four thermometers were prepared for testing by annealing them for 30 min at or near the gold point, and then slow-cooling them to about $520^{\circ} \mathrm{C}$.

The NBS thermometers had also been stabilized by heat treatment, as indicated in table 2 and figure 2 . One of the four thermometers originally made for the investigation (8203) failed during the stabilization process because of internal lead separation. It therefore could not be included in any of the experiments.

\section{Experimental Procedures and Results}

Unless otherwise indicated, the general methods and equipment described above were used throughout the experiments. The internal guard of the guarded lead thermometers was connected to the bridge guard circuit during measurement [13], except for special tests. All experimental results are reported in the appendix tables. The values of resistance in the tables are given by

$$
R=10 \times R(\mathrm{th}) / R(\mathrm{sr}),
$$




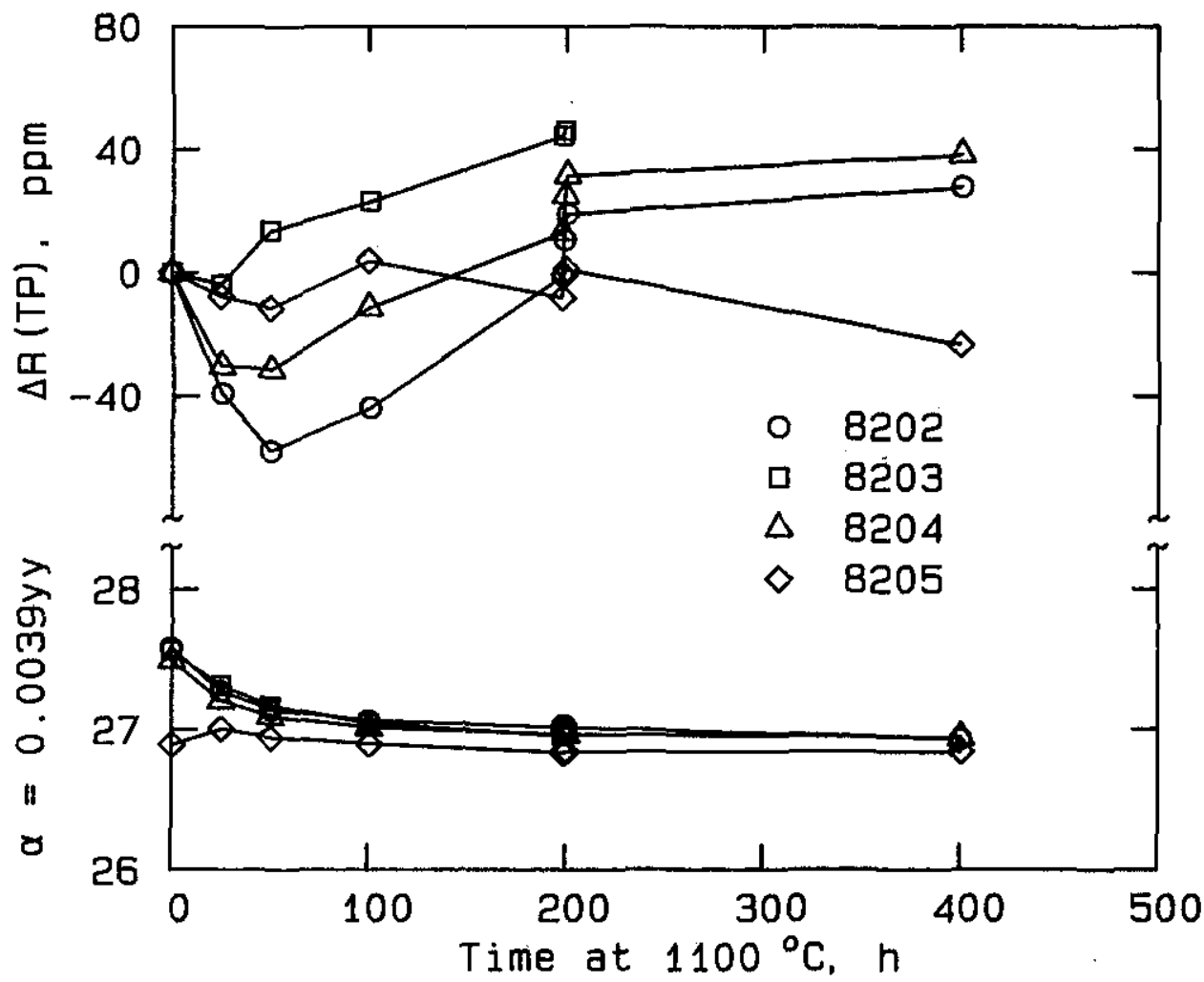

Figure 2-Change in characteristics of NBS thermometers during stabilization. Both the relative change in thermometer resistance at the triple point of water (parts in $10^{6}, \mathrm{ppm}$ ) and the alpha coefficient, $\alpha$, are shown.

where $R($ th) is the value of the thermometer and $R(\mathrm{sr})$ is the value of the standard resistor, as measured by the bridge. The factor $10 \mathrm{in} \mathrm{eq} \mathrm{(1)} \mathrm{is} \mathrm{the} \mathrm{nominal} \mathrm{resistance}$ of the standard resistor; it is included so that $R$ is approximately in ohms. If the factor were to be replaced by the actual value of the standard resistor in absolute ohms, then $R$ would also be in absolute ohms. This was not considered necessary for the present investigation because all results were derived from ratios of $R$ values. In the time required to obtain the values of $R$ for a single ratio, the standard resistor did not change significantly.

The first experiment consisted of two runs (series of measurements of thermometer resistance at fixed points) with an intervening exposure of the thermometers to high temperature. In the first run, the resistance of a thermometer was determined at thermometric fixed points in the sequence TP, AU, TP, AG, TP; AL, TP, $\mathrm{ZN}, \mathrm{TP}, \mathrm{SN}, \mathrm{TP}$, where TP designates the triple point of water and $A U, A G, A L, Z N, S N$ designate the freezing points of gold, silver, aluminum, zinc, and tin, respectively. Three or four thermometers were measured in a single freeze at the tin, zinc, and aluminum points, but at the gold and silver points, separate freezes were used for each thermometer. The measurements were made with the thermometer fully immersed in the freezing-point cells and in the triple-point cell. Thermometer resistance was determined both with the nor - mal measuring current and with twice the normal current; the value of resistance for zero power dissipation was calculated from these two determinations. The thermometer was then heated in a vertical position at $1100^{\circ} \mathrm{C}$ for $100 \mathrm{~h}$ and cooled slowly as described above (sec. 2.1), and the measurement sequence was repeated for the second run. The results are given in tables Ala-g of the appendix.

The second experiment was conducted at the silver point. A "mesh" made of $0.25 \mathrm{~mm}$ diameter platinum wire was placed around the sheath of a thermometer before it was inserted into the silver freezing-point cell. Upon insertion, the mesh was situated in the small annulus between the silica-glass sheath of the thermometer and the silica-glass cell guide tube and cell well, thus preventing direct contact between the sheath and the guide tube and well. The mesh extended all the way from the bottom of the thermometer to the top of the cell guide tube at room temperature, where it was connected electrically to the bridge guard circuit, forming an external electrical thermometer guard. Thermometer resistance determinations were made, with the normal measuring current, at $5 \mathrm{~min}$ intervals as the silver was allowed to freeze slowly. From time to time the connection between the bridge guard circuit and the thermometer guards was changed, or the guard circuit was disconnected completely. Results for all thermometers 
except No. 18227 (NIM) are given in tables A2a-f of the appendix.

Thermometer No. 18227 was not tested in the second experiment because the slightly larger diameter of its sheath did not leave enough room in the cell well to accommodate the wire mesh. Similarly, the slightly smaller diameter of the gold-point cell well prevented the use of the external guard with any of the thermometers at the gold point.

In the third experiment the immersion characteristics of the thermometers were compared at the freezing point of zinc. The zinc point was chosen for this experiment because electrical leakage effects were negligible, and because it was easy to establish long periods of constant temperature. Only the normal measuring current was used; precise determination of variations in thermometer self-heating would have been obscured by the limited bridge resolution of the thermometers' low resistance. Measurements were made at $5 \mathrm{~min}$ intervals at various vertical stations (in $\mathrm{cm}$ ) in the cell well. The results are given in tables A3a-b of the appendix. At station 0 , the thermometer sheath was fully immersed in and resting on the bottom of the cell well.

\section{Analysis of Data}

\subsection{First Experiment}

The data obtained in the first experiment may be analyzed by deriving the resistance ratio at each fixed point from the resistance values given in tables Ala-g. The resistance ratio at a fixed point, designated by $W(\mathrm{FP})$, is defined by

$$
W(\mathrm{FP})=R(\mathrm{FP}) / R(0) .
$$

$R(\mathrm{FP})$ is the resistance at the fixed point taken from the tables. $R(0)$ is the associated value of thermometer resistance at $0^{\circ} \mathrm{C}$; it is derived from the mean of the values of $R(\mathrm{TP})$ immediately preceding and following $R(\mathrm{FP})$ in the tables, taking into account a correction for the depth of immersion of the thermometer in the triplepoint cell. The values of $W(\mathrm{FP})$ are listed in table 3.

It is convenient to interpret resistance ratios and their differences in terms of temperature values. To do this,

Table 3. Resistance ratios at fixed points. ${ }^{1,2}$

\begin{tabular}{|c|c|c|c|c|c|}
\hline Run & $W(\mathrm{AU})$ & $W(\mathrm{AG})$ & $W(\mathrm{AL})$ & $W(\mathrm{ZN})$ & $W(\mathrm{SN})$ \\
\hline \multicolumn{6}{|l|}{ RT no. 80179} \\
\hline 1 & 4.57174066 & 4.28647159 & 3.37604256 & 2.56895487 & 1.89283568 \\
\hline 2 & 4.57168631 & 4.28642060 & 3.37600925 & 2.56893131 & 1.89282128 \\
\hline \multicolumn{6}{|l|}{ RT no. 18227} \\
\hline 1 & 4.57157254 & 4.28629894 & 3.37591813 & 2.56886467 & 1.89278068 \\
\hline 2 & 4.57151496 & 4.28623733 & 3.37587016 & 2.56883989 & 1.89276336 \\
\hline \multicolumn{6}{|l|}{ RT no. 18236} \\
\hline 1 & 4.57148343 & 4.28625191 & 3.37588957 & 2.56884678 & 1.89277435 \\
\hline 2 & 4.57147650 & 4.28622095 & 3.37585840 & 2.56882739 & 1.89275797 \\
\hline RT no. 18237 & . & & & & \\
\hline 1 & 4.57149741 & 4.28628074 & 3.37591249 & 2.56886121 & 1.89277637 \\
\hline 2 & 4.57145197 & 4.28622217 & 3.37586485 & 2.56883266 & 1.89276204 \\
\hline \multicolumn{6}{|l|}{ RT no. 8202} \\
\hline 1 & 4.57150591 & 4.28624231 & 3.37592544 & 2.56888096 & 1.89279537 \\
\hline 2 & 4.57147188 & 4.28622642 & 3.37590991 & 2.56887218 & 1.89279135 \\
\hline \multicolumn{6}{|l|}{ RT no. 8204} \\
\hline 1 & 4.57152289 & 4.28627237 & 3.37594233 & 2.56888153 & 1.89279772 \\
\hline 2 & 4.57153108 & 4.28627577 & 3.37594331 & 2.56887922 & 1.89279320 \\
\hline \multicolumn{6}{|l|}{ RT no. 8205} \\
\hline 1 & 4.57137553 & 4.28617237 & 3.37587835 & 2.56884607 & 1.89277446 \\
\hline 2 & 4.57136712 & 4.28614094 & 3.37586420 & 2.56884047 & 1.89277239 \\
\hline
\end{tabular}

${ }^{1}$ Values derived from resistance values given in tables Ala-g.

${ }^{2} W(\mathrm{FP})=R(\mathrm{FP}) / R(0)$, where $R(0)$ is derived from the mean of the values of $R(\mathrm{TP})$ before and after $R(\mathrm{FP})$. 
we define a simple "temperature scale" on which values of temperature (designated by $t^{\prime}$ ) lie close to values on ordinary scales. The resistance ratio of a thermometer is related to a value on the scale by

$$
W\left(t^{\prime}\right)=1+A t^{\prime}+B t^{\prime 2}
$$

The coefficients $A$ and $B$ are determined from the values of $W(\mathrm{SN})$ and $W(\mathrm{ZN})$ in table 3 using the IPTS-68 assigned values of $t^{\prime}$ at the tin and zinc points, but taking into account corrections due to thermometer immersion. The values of $A$ and $B$ are listed in table 4, along with values of the coefficients alpha, $\alpha$, and delta, $\delta$, related to $A$ and $B$ by

$$
\alpha=A+100 B ; \quad \delta=-10^{4} B /(A+100 B) .
$$

The values of $t^{\prime}$ calculated from the values of $W(\mathrm{AL})$, $W(\mathrm{AG})$, and $W(\mathrm{AU})$ in table 3 , using eq (3), represent values of temperature in the respective metal freezing point cells during freezing experiments, specifically at the mid-point of the resistor of a fully immersed ther- mometer. The values obtained from runs 1 and 2 are listed in table 5 .

Table 6 summarizes pertinent statistics of the values in table 5. The data are analyzed in various subsets and combinations of subsets as indicated. "Mean" is the arithmetic mean of the equally weighted values in the subset. "SD" is the estimate of the standard deviation of one value in the subset derived from the data in the subset. "Range" is the difference between the maximum and minimum values in the subset. All values are given in "degrees" on the "temperature scale"-close to degrees C or kelvins on ordinary scales.

Table 7 gives the temperature equivalents of the resistance ratio changes between run 1 and run 2 . The temperature differences are estimated from

$$
\Delta t=\Delta W /(\mathrm{d} W / \mathrm{d} t)
$$

where $\Delta W=W($ run 2$)-W($ run 1$)$, and $W($ run 1$)$ is the value of $W(\mathrm{FP})$ determined in run 1 at a fixed point, and $W$ (run 2) is the value of $W(\mathrm{FP})$ at the same fixed point determined during run 2 , both taken from table 3 . The

\begin{tabular}{|c|c|c|c|c|}
\hline Run & $A$ & $B$ & $\alpha$ & $\delta$ \\
\hline \multicolumn{5}{|c|}{ RT no. 80179} \\
\hline 1 & $3985.8728 \mathrm{E}-6^{3}$ & $-0.58756370 \mathrm{E}-6$ & $3927.1164 \mathrm{E}-6$ & 1.4961708 \\
\hline 2 & $3985.8033 \mathrm{E}-6$ & $-0.58753192 \mathrm{E}-6$ & $3927.0502 \mathrm{E}-6$ & 1.4961151 \\
\hline \multicolumn{5}{|c|}{ RT no. 18227} \\
\hline 1 & $3985.6083 \mathrm{E}-6$ & $-0.58744562 \mathrm{E}-6$ & $3926.8637 \mathrm{E}-6$ & 1.4959664 \\
\hline 2 & $3985.5143 \mathrm{E}-6$ & $-0.58736232 \mathrm{E}-6$ & $3926.7781 \mathrm{E}-6$ & 1.4957869 \\
\hline \multicolumn{5}{|c|}{ RT no. 18236} \\
\hline 1 & $3985.6000 \mathrm{E}-6$ & $-0.58752738 \mathrm{E}-6$ & $3926.8472 \mathrm{E}-6$ & 1.4961809 \\
\hline 2 & $3985.4992 \mathrm{E}-6$ & $-0.58739730 \mathrm{E}-6$ & $3926.7594 \mathrm{E}-6$ & 1.4958831 \\
\hline \multicolumn{5}{|c|}{ RT no. 18237} \\
\hline 1 & $3985.5769 \mathrm{E}-6$ & $-0.58739055 \mathrm{E}-6$ & 3926.8379E-6 & 1.4958360 \\
\hline 2 & $3985.5229 \mathrm{E}-6$ & $-0.58742386 \mathrm{E}-6$ & $3926.7805 \mathrm{E}-6$ & 1.4959427 \\
\hline \multicolumn{5}{|c|}{ RT no. 8202} \\
\hline 1 & $3985.7019 \mathrm{E}-6$ & $-0.58757620 \mathrm{E}-6$ & $3926.9443 \mathrm{E}-6$ & 1.4962682 \\
\hline 2 & $3985.6890 \mathrm{E}-6$ & $-0.58759525 \mathrm{E}-6$ & $3926.9295 \mathrm{E}-6$ & 1.4963224 \\
\hline \multicolumn{5}{|c|}{ RT no. 8204} \\
\hline 1 & 3985.7229E-6 & $-0.58762304 \mathrm{E}-6$ & $3926.9606 \mathrm{E}-6$ & 1.4963813 \\
\hline 2 & $3985.6862 \mathrm{E}-6$ & $-0.58754853 \mathrm{E}-6$ & $3926.9313 \mathrm{E}-6$ & 1.4962027 \\
\hline \multicolumn{5}{|c|}{ RT no. 8205} \\
\hline 1 & $3985.6031 \mathrm{E}-6$ & $-0.58753878 \mathrm{E}-6$ & 3926.8492E-6 & 1.4962092 \\
\hline 2 & $3985.5996 \mathrm{E}-6$ & $-0.58756233 \mathrm{E}-6$ & $3926.8434 \mathrm{E}-6$ & 1.4962714 \\
\hline
\end{tabular}
derivative $d W / \mathrm{d} T$, obtained by differentiating eq (3), is

Table 4. Calibration coefficients. ${ }^{1,2}$

${ }^{\prime} W\left(t^{\prime}\right)=1+A t^{\prime}+B t^{\prime 2}$.

${ }^{2}$ Coefficients derived from values of $W(\mathrm{ZN})$ and $W(\mathrm{SN})$ and IPTS-68 assigned values of $t^{\prime}(\mathrm{ZN})$ and $t^{\prime}(\mathrm{SN})$

${ }^{3}$ The notation E-6 signifies multiplication by $10^{-6}$. 
Table 5. Derived values of $t^{\prime}$ at $A U, A G$, and AL. ${ }^{1.2}$

\begin{tabular}{lcccccc}
\hline \hline & \multicolumn{2}{c}{$t^{\prime}(\mathrm{AU})$} & \multicolumn{2}{c}{$t^{\prime}$ (AG) } & & $t^{\prime}(\mathrm{AL})$ \\
\hline RT no. & Run 1 & Run 2 & Run 1 & Run 2 & Run 1 & Run 2 \\
\hline 80179 & 1062.5201 & 1062.5141 & 960.5363 & 960.5315 & 660.4079 & 660.4075 \\
18227 & 1062.5127 & 1062.4938 & 960.5266 & 960.5098 & 660.4075 & 660.4006 \\
18236 & 1062.5171 & 1062.5004 & 960.5394 & 960.5204 & 660.4114 & 660.4048 \\
18237 & 1062.4747 & 1062.4928 & 960.5130 & 960.5215 & 660.4047 & 660.4055 \\
& & & & & \\
8202 & 1062.5059 & 1062.5063 & 960.5175 & 960.5225 & 660.4082 & 660.4086 \\
8204 & 1062.5232 & 1062.5098 & 960.5361 & 960.5256 & 660.4155 & 660.4133 \\
8205 & 1062.4812 & 1062.4892 & 960.5142 & 960.5120 & 660.4088 & 660.4083 \\
\hline
\end{tabular}

${ }^{\prime} W\left(t^{\prime}\right)=1+A t^{\prime}+B t^{\prime 2}$.

${ }^{2}$ Values of $t$ ' derived from values of $W(F P)$ in table 3 and values of the coefficients in table 4.

Table 6. Statistics of $t^{\prime}$

\begin{tabular}{|c|c|c|c|c|}
\hline $\begin{array}{l}\text { RT } \\
\text { set }\end{array}$ & & Run 1 & Run 2 & $\begin{array}{l}\text { Combined } \\
\text { runs }\end{array}$ \\
\hline \multicolumn{5}{|c|}{ at gold point (Au) } \\
\hline \multirow[t]{3}{*}{ NIM } & Mean & 1062.5062 & 1062.5003 & 1062.5032 \\
\hline & $\mathrm{SD}^{2}$ & 0.0212 & 0.0098 & 0.0156 \\
\hline & Range & 0.0454 & 0.0213 & 0.0454 \\
\hline \multirow[t]{3}{*}{ NBS } & Mean & 1062.5034 & 1062.5018 & 1062.5026 \\
\hline & $\mathrm{SD}$ & 0.0211 & 0.0110 & 0.0151 \\
\hline & Range & 0.0420 & 0.0206 & 0.0420 \\
\hline Com- & Mean & 1062.5050 & 1062.5009 & 1062.5030 \\
\hline bined & SD & 0.0194 & 0.0094 & 0.0148 \\
\hline Set & Range & 0.0485 & 0.0249 & 0.0485 \\
\hline \multicolumn{5}{|c|}{ at silver point ( $\mathrm{AG}$ ) } \\
\hline \multirow[t]{3}{*}{ NIM } & Mean & 960.5288 & 960.5208 & 960.5248 \\
\hline & SD & 0.0119 & 0.0089 & 0.0106 \\
\hline & Range & 0.0264 & 0.0217 & 0.0296 \\
\hline \multirow[t]{3}{*}{ NBS } & Mean & 960.5226 & $960.5: 200$ & 960.5213 \\
\hline & $\mathrm{SD}$ & 0.0118 & 0.0071 & 0.0088 \\
\hline & Range & 0.0219 & 0.0136 & 0.0241 \\
\hline Com- & Mean & 960.5262 & 960.5205 & 960.5233 \\
\hline bined & $\mathrm{SD}$ & 0.0113 & 0.0075 & 0.0097 \\
\hline set & Range & 0.0264 & 0.0217 & 0.0296 \\
\hline \multicolumn{5}{|c|}{ at aluminum point (AL) } \\
\hline \multirow[t]{3}{*}{ NIM } & Mean & 660.4079 & 660.4046 & 660.4062 \\
\hline & SD & 0.0027 & 0.0029 & 0.0031 \\
\hline & Range & 0.0067 & 0.0069 & 0.0108 \\
\hline \multirow[t]{3}{*}{ NBS } & Mean & 660.4108 & 660.4101 & 660.4104 \\
\hline & SD & 0.0041 & 0.0028 & 0.0031 \\
\hline & Range & 0.0073 & 0.0050 & 0.0073 \\
\hline Com- & Mean & 660.4091 & 660.4069 & 660.4080 \\
\hline bined & SD & 0.0034 & 0.0039 & 0.0037 \\
\hline set & Range & 0.0108 & 0.0127 & 0.0149 \\
\hline
\end{tabular}

'Statistics derivec from values of $t$ ' in table 5 .

${ }^{2} \mathrm{SD}$ : estimate of standard deviation of one value in indicated set. evaluated using the coefficients from table 4 and the mean value of $t^{\prime}$ at the fixed point given in table 6 or the value of $t^{\prime}$ assigned to the fixed point.

It is instructive to evaluate $t^{\prime}$ from the values of $W(\mathrm{AU}), W(\mathrm{AG})$, and $W(\mathrm{AL})$ determined in run 2 using the values of the coefficients determined in run 1 . The results of this procedure are given in table 8; these values are to be compared with the original run 1 values in tables 5 and 6 . It can be seen that the temperature differences are the same as the temperature equivalent changes shown in table 7. This is to be expected, since both evaluations are based on the same "calibration coefficients"; the changes are thus due only to the changes in $W(\mathrm{AU}), W(\mathrm{AG})$, and $W(\mathrm{AL})$ between the two runs. A comparison of the statistics in table 8 with those in table 6 show that upon prolonged heating at high temperature the thermometers may change, resulting in changes in temperature values and increases in standard deviation and range if the thermometers are not recalibrated. Table 8 also shows similar results using run 2 coefficients and run 1 resistance ratios.

The results of an analysis at the silver point using a different "temperature scale" formulation are given in table 9. In this case, $t$ " is defined in terms of a quadratic relation between $W\left(t^{\prime \prime}\right)$ and $t^{\prime \prime}$, as in eq (3), but with the coefficients determined at the aluminum and gold points (and at $0^{\circ} \mathrm{C}$ ). The coefficients are determined from the values of $W(\mathrm{AL})$ and $W(\mathrm{AU})$ given in table 3 ; the values of $t^{\prime \prime}$ assigned to these points, $t^{\prime \prime}(\mathrm{AL})=660.408$ and $t^{\prime \prime}(\mathrm{AU})=1062.503$, are the means of the combined sets and runs at the aluminum and gold points given in table 6 . The statistics in table 9 are analogous to the statistics for $t^{\prime}$ at the silver point given in table 6 .

The value of $R(\mathrm{TP})$ was determined six times for each thermometer during each of the two runs, as indicated in tables Ala-g. Table 10 presents a summary of the changes that occurred in $R$ (TP). The numbers in the table give relative, or fractional, changes in parts per million (parts in $10^{6}$ ). The "Range" for a thermometer is 
Table 7. Temperature equivalent of resistance ratio changes. ${ }^{1,2}$

\begin{tabular}{lccccc}
\hline \hline RT no. & AU & AG & AL & ZN & SN \\
\hline 80179 & -0.0199 & -0.0179 & -0.0104 & -0.0068 & -0.0039 \\
18227 & -0.0211 & -0.0216 & -0.0149 & -0.0071 & -0.0047 \\
18236 & -0.0025 & -0.0109 & -0.0097 & -0.0056 & -0.0044 \\
18237 & -0.0166 & -0.0206 & -0.0148 & -0.0082 & -0.0039 \\
Mean & -0.0150 & -0.0177 & -0.0125 & -0.0069 & -0.0042 \\
\hline 8202 & -0.0125 & -0.0056 & -0.0048 & -0.0025 & -0.0011 \\
8204 & 0.0030 & 0.0012 & 0.0003 & -0.0007 & -0.0012 \\
8205 & -0.0031 & -0.0110 & -0.0044 & -0.0016 & -0.0006 \\
Mean & -0.0042 & -0.0051 & -0.0030 & -0.0016 & -0.0010 \\
\hline Combined & & & & & \\
Mean & -0.0104 & -0.0123 & -0.0084 & & \\
\hline
\end{tabular}

${ }^{1}$ Values derived from difference (run 2-run 1) in resistance ratio values given in table 3.

${ }^{2}$ Values expressed in terms of $t$.

Table 8. Derived values of $t^{\prime}$ at $\mathrm{AU}, \mathrm{AG}$, and AL. ${ }^{1,2}$

\begin{tabular}{|c|c|c|c|}
\hline \multicolumn{4}{|c|}{ Run 1 coefficients; run $2 W(\mathrm{AU}), W(\mathrm{AG}), W(\mathrm{AL})$} \\
\hline RT no. & $t^{\prime}(\mathrm{AU})$ & $t^{\prime}(\mathbf{A G})$ & $t^{\prime}(\mathbf{A L})$ \\
\hline 80179 & 1062.5003 & 960.5184 & 660.3975 \\
\hline 18227 & 1062.4917 & 960.5051 & 660.3925 \\
\hline 18236 & 1062.5146 & 960.5286 & 660.4017 \\
\hline 18237 & 1062.4581 & 960.4925 & 660.3898 \\
\hline 8202 & 1062.4934 & 960.5120 & 660.4034 \\
\hline 8204 & 1062.5262 & 960.5373 & 660.4158 \\
\hline 8205 & 1062.4781 & 960.5032 & 660.4052 \\
\hline Mean & 1062.4946 & 960.5139 & 660.4008 \\
\hline $\mathbf{S D}^{3}$ & 0.0225 & 0.0155 & 0.0087 \\
\hline Range & 0.0681 & 0.0448 & 0.0260 \\
\hline \multicolumn{4}{|c|}{ Run 2 coefficients; run $1 W(\mathrm{AU}), W(\mathrm{AG}), W(\mathrm{AL})$} \\
\hline RT no. & $t^{\prime}(\mathrm{AU})$ & $t^{\prime}(\mathrm{AG})$ & $t^{\prime}(\mathrm{AL})$ \\
\hline 80179 & 1062.5340 & 960.5494 & 660.4178 \\
\hline 18227 & 1062.5148 & 960.5314 & 660.4155 \\
\hline 18236 & 1062.5026 & 960.5313 & 660.4145 \\
\hline 18237 & 1062.5094 & 960.5420 & 660.4203 \\
\hline 8202 & 1062.5188 & 960.5280 & 660.4135 \\
\hline 8204 & 1062.5068 & 960.5244 & 660.4130 \\
\hline 8205 & 1062.4922 & 960.5230 & 660.4127 \\
\hline Mean & 1062.5112 & 960.5328 & 660.4153 \\
\hline SD & 0.0132 & 0.0096 & 0.0028 \\
\hline Range & 0.0418 & 0.0264 & 0.0076 \\
\hline
\end{tabular}

${ }^{1} W\left(t^{\prime}\right)=1+A t^{\prime}+B t^{2}$

${ }^{2}$ alues of $t$ ' derived from indicated values of W(FP) in table 3 and indicated values of the coefficients in table 4.

${ }^{3} \mathrm{SD}$ : estimate of standard deviation of one value in set.
Table 9. Statistics of $t^{*}$ at silver point.,

\begin{tabular}{llrrr}
\hline $\begin{array}{l}\text { RT } \\
\text { set }\end{array}$ & & \multicolumn{1}{c}{ Run 1 } & \multicolumn{1}{c}{ Run 2 } & $\begin{array}{c}\text { Combined } \\
\text { runs }\end{array}$ \\
\hline NIM & Mean & 960.5269 & 960.5240 & 960.5254 \\
& SD $^{3}$ & 0.0052 & 0.0042 & 0.0046 \\
& Range & 0.0121 & 0.0103 & 0.0139 \\
NBS & Mean & 960.5211 & 960.5200 & 960.5206 \\
& SD & 0.0063 & 0.0009 & 0.0041 \\
& Range & 0.0124 & 0.0018 & 0.0124 \\
Com- & Mean & 960.5244 & 960.5223 & 960.5233 \\
bined & SD & 0.0060 & 0.0038 & 0.0049 \\
set & Range & 0.0171 & 0.0103 & 0.0171 \\
\hline
\end{tabular}

${ }^{1} W\left(t^{\prime \prime}\right)=1+a t^{\prime \prime}+b t^{* 2}$, where the coefficients $a$ and $b$ are determined from values of $W(\mathrm{AL})$ and $W(\mathrm{AU})$ given in table 6 , and $t^{\prime \prime}(\mathrm{AL})=660.408$, $t^{\prime \prime}(\mathrm{AU})=1062.503$ (see table 6 ).

${ }^{2}$ Values of $t^{\prime \prime}(\mathrm{AG})$ derived from values of W(AG) given in table 3 asing the above equation.

${ }^{3} \mathrm{SD}$ : estimate of standard deviation of one value in indicated set.

the difference between the largest and the smallest of its six $R(\mathrm{TP})$ values in a run. The other two statistics, "Max" and "RMS," deal with successive differences between values of $R(T P)$ in a given run. These successive differences are of interest because the value of $W(\mathrm{FP})$ is calculated from the mean of successive values of $R(\mathrm{TP})$ bracketing a value of $R(\mathrm{FP})$. "Max" is the largest of such successive differences in a run, without regard to sign of the difference. "RMS" is the square root of the mean of the squares of such successive differences.

\subsection{Second Experiment}

The data obtained in the second experiment may be examined by plotting thermometer resistance as a func- 
Table 10. Variations in $R(\mathrm{TP})$. $^{1}$

(Values given are parts in $\left.10^{6}\right)^{2}$

\begin{tabular}{lcccccc}
\hline & \multicolumn{3}{c}{ Run 1 } & \multicolumn{3}{c}{ Run 2 } \\
\cline { 2 - 7 } RT no. & Range $^{3}$ & Max $^{4}$ & RMS $^{5}$ & Range & Max & RMS \\
\hline 80179 & 5.6 & 4.8 & 3.2 & 7.6 & 5.0 & 3.0 \\
18227 & 2.8 & 2.5 & 1.4 & 2.0 & 2.0 & 1.6 \\
18236 & 4.8 & 4.8 & 2.9 & 2.6 & 1.7 & 1.1 \\
18237 & 3.2 & 3.2 & 2.3 & 6.1 & 2.9 & 1.9 \\
& & & & & & \\
8202 & 8.3 & 5.5 & 2.9 & 2.5 & 2.5 & 1.9 \\
8204 & 7.0 & 4.0 & 2.3 & 5.7 & 5.0 & 3.2 \\
8205 & 3.8 & 2.3 & 1.4 & 9.5 & 5.5 & 3.1 \\
\hline
\end{tabular}

'Values derived from values of $R(\mathrm{TP})$ in tables A1a-g.

${ }^{2} \mathrm{~A}$ fractional difference in $R(\mathrm{TP})$ of $4 \times 10^{-6}$ is equivalent to a temperature interval of about $1 \mathrm{mK}$ at the triple point of water.

${ }^{3}$ Range: fractional difference between largest and smallest value of $R(\mathrm{TP})$ in a single run.

${ }^{4}$ Max: magnitude of largest fractional difference between two successive values of $R(\mathrm{TP})$ in a single run.

${ }^{5} \mathrm{RMS}$; root-mean-square of fractional differences between successive values of $R(\mathrm{TP})$ in a single run.

tion of time. Figures $3-8$ are plots of the data given in tables A2a-f. The data points show results of the various electrical guard configurations; the data for each are connected by solid lines to form "freezing curves" of the silver as it solidified. For the NIM thermometers, the only possible guard configurations were with the external guard connected to or disconnected from the bridge guard driving circuit, since the thermometers had no internal guarding system. The NBS thermometers were measured with both the internal and external guards connected to the drive circuit, with only the external guard connected, with only the internal guard connected, or with neither guard connected. The various configurations are labeled in the figures. The tem. perature scaling brackets shown in the figures are estimated from the relation

$$
\Delta t=(\Delta R / R) \times W /(\mathrm{d} W / \mathrm{d} t)
$$

where $R$ is thermometer resistance at the silver point, $W$ is $W(\mathrm{AG})$ taken from table 3 , and the derivative $\mathrm{d} W / \mathrm{d} t$, found by differentiating eq (3), is evaluated at the silver point using the coefficients in table 4 and the mean value of $t^{\prime}(\mathrm{AG})$ in table 6.

\subsection{Third Experiment}

The data obtained in the third experiment may also be examined by plotting. In this case the differences between thermometer indications at full immersion and at reduced immersion are plotted as a function of immersion. We start by computing for each thermometer the resistance differences,

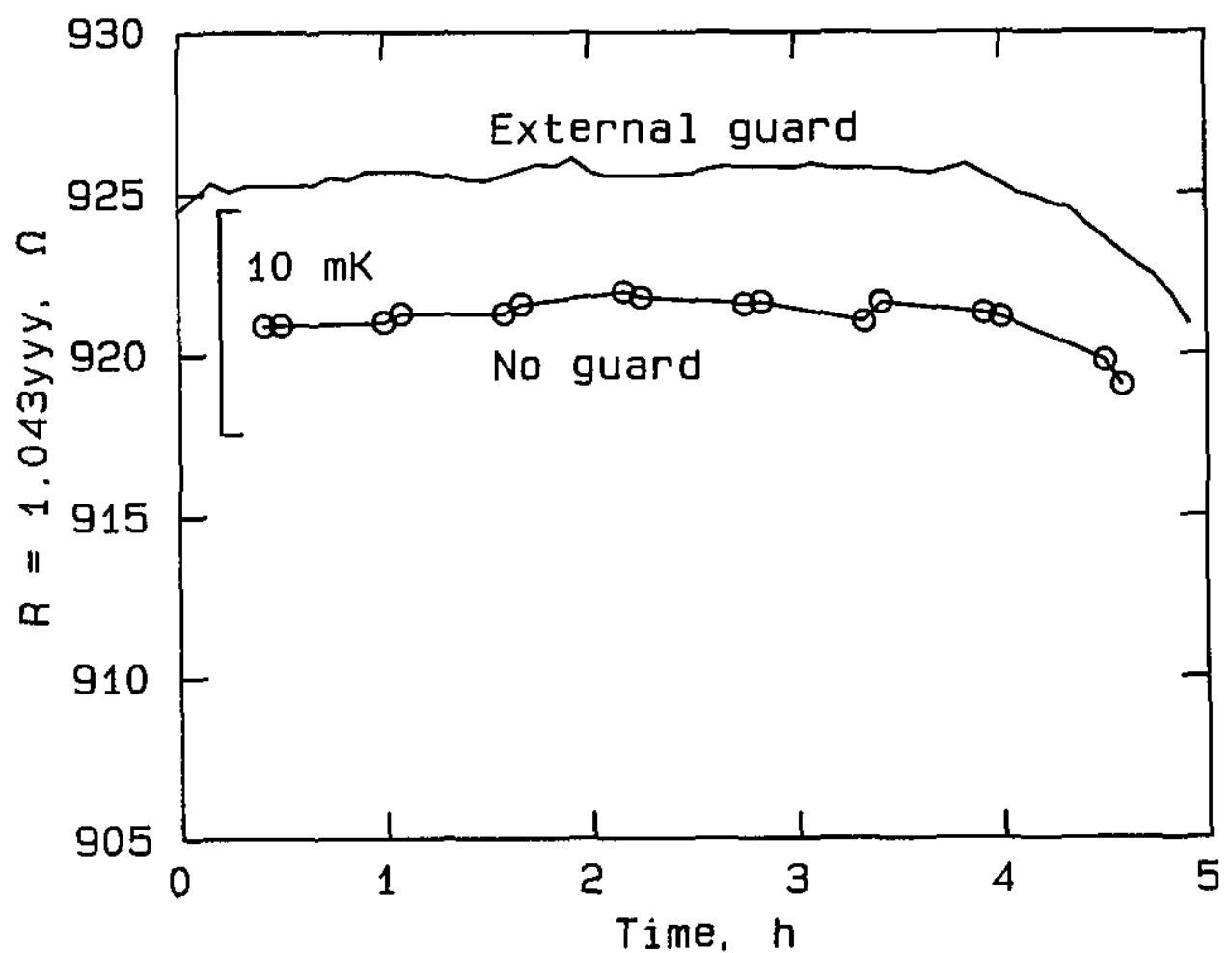

Figure 3-Effect of guarding at silver point, RT No. 80179, plotted from the data in table A2a. The curve labeled "External guard" represents measurements taken with the external guard connected to the bridge guard circuit. The curve labeled "No guard" represents measurements taken with the guard disconnected. 

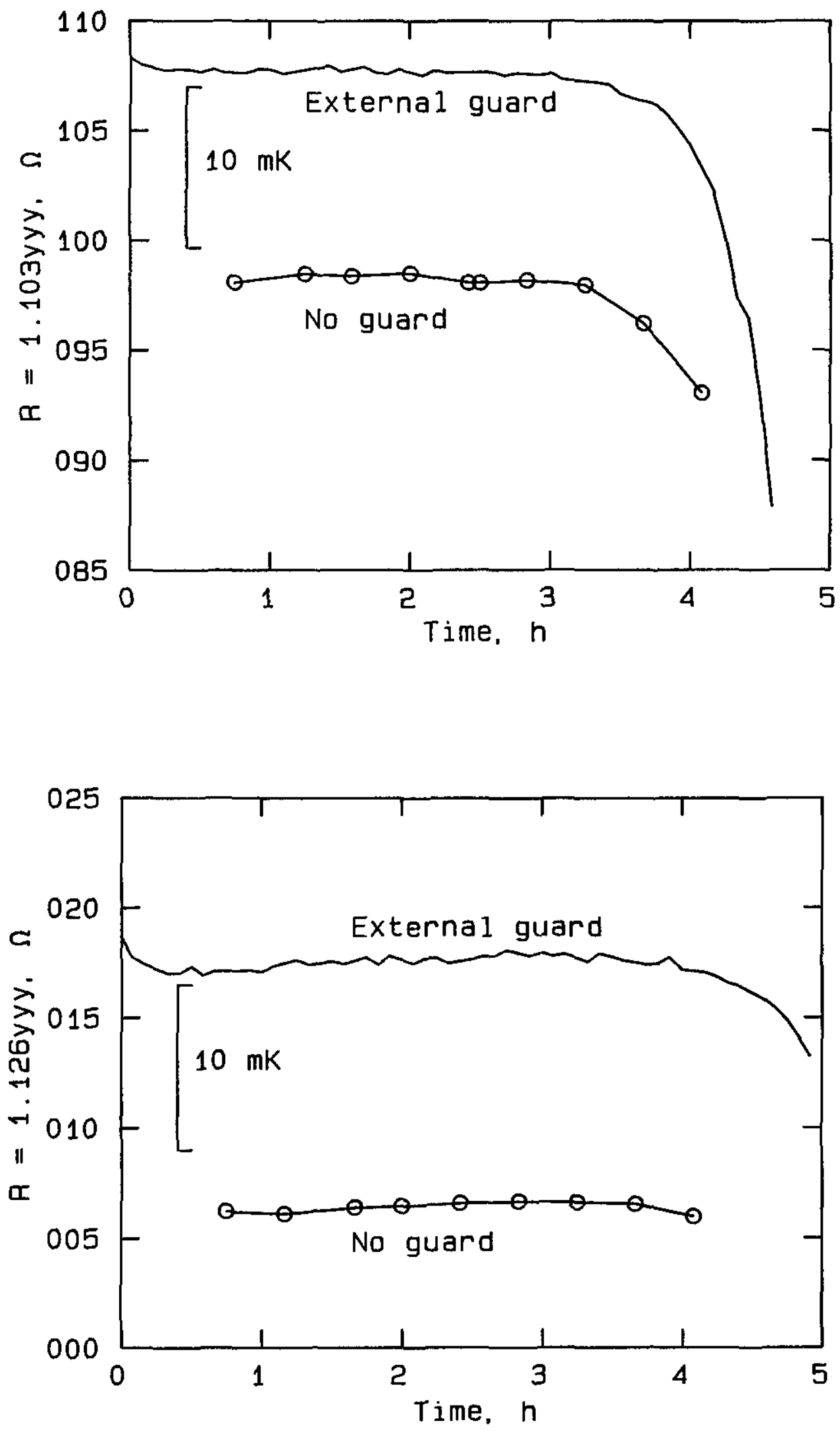

Figure 4-Effect of guarding at silver point, RT No. 18236, plotted from the data in table A2b. The curve labeled "External guard" represents measurements taken with the external guard connected to the bridge guard circuit. The curve labeled "No guard" represents measurements taken with the guard discon

Figure 5-Effect of guarding at silver point, RT No. 18237 , plotted from the data in table A2c. The curve labeled "External guard" represents measurements taken with the external guard connected to the bridge guard circuit. The curve labeled "No guard" represents measurements taken with the guard disconnected. 

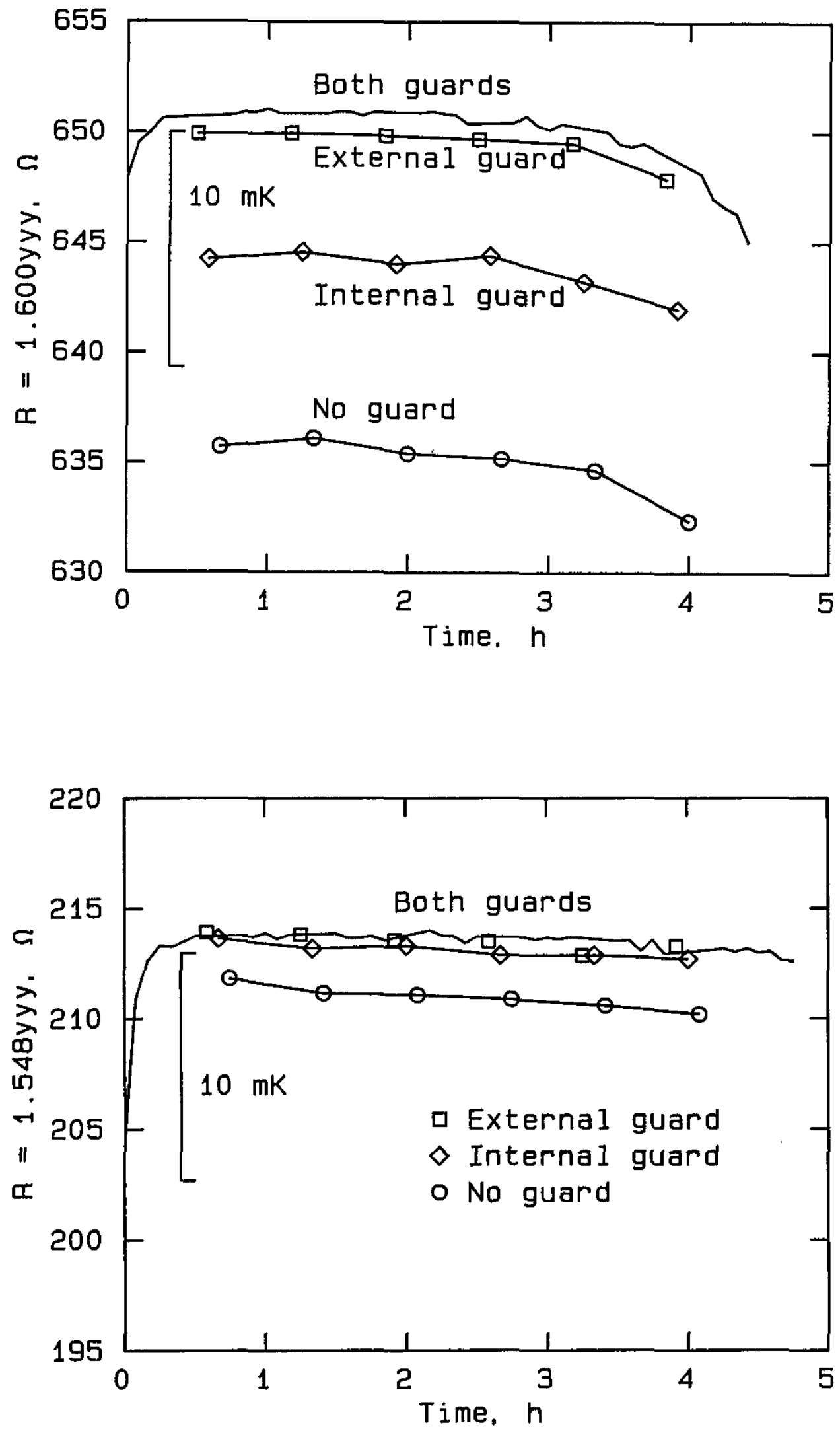

Figure 6-Effect of guarding at silver point, RT No. 8202 , plotted from the data in table A2d. The curve labeled "Both guards" represents measurements taken with both the external guard and the internal thermometer guard connected to the bridge guard circuit. The curve labeled "External guard" represents measurements taken with only the external guard connected, and the curve labeled "Internal guard" represents measurements taken with only the internal guard connected. The curve labeled "No guard" represents measurements taken with neither guard connected to the bridge guard circuit.
Figure 7-Effect of guarding at silver point, RT No. 8204, plotted from the data in table A2e. The curve labeled "Both guards" represents measurements taken with both the external guard and the internal thermometer guard connected to the bridge guard circuit. The unlabeled points lying on or close to the curve, designated by unconnected open symbols, represent measurements taken with only the external guard connected. The curve labeled "Internal guard" represents measurements taken with only the internal guard connected. The curve labeled "No guard" represents measurements taken with neither guard connected to the bridge guard circuit. 


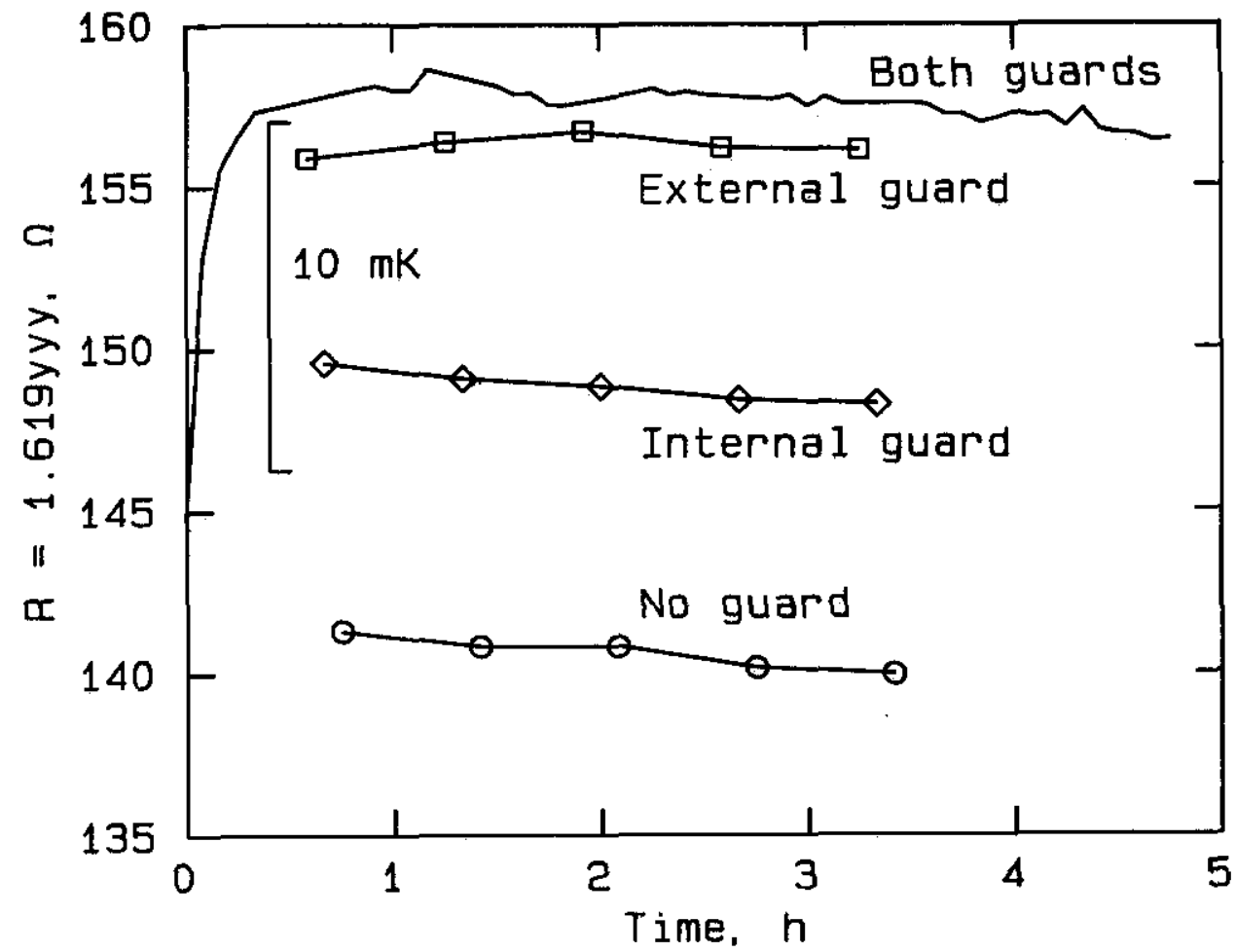

Figure 8-Effect of guarding at silver point, RT No. 8205, plotted from the data in table A2f. The curve labeled "Both guards" represents measurements taken with both the external guard and the internal thermometer guard connected to the bridge guard circuit. The curve labeled "External guard" represents measurements taken with only the external guard connected, and the curve labeled "Internal guard" represents measurements taken with only the internal guard connected. The curve lan beled "No guard" represents measurements taken with neither guard connected to the bridge guard circuit.

$$
\Delta R=R(\text { station } x)-R(\text { station } 0),
$$

from the data in tables A.3a and A3b. $R$ (station $x$ ) is the resistance measured when the thermometer is at one of the stations above station $0 . R$ (station 0 ) is the average of resistance measurements at station 0 before and after the measurement at station $x$. The resistance differences are then converted to equivalent temperature differences using eq (6), but with the second term evaluated for the zinc point. The resulting temperature differences are plotted as a function of immersion station up to station 10 in figures 9 and 10 . The straight line with intercept at $\Delta t=0$ in the plots represents the expected decrease in temperature with immersion due to the hydrostatic pressure of the liquid metal.

\section{Evaluation of Thermometer Characteristics}

\subsection{Long-Time Stability at High Temperature}

The effect of $100 \mathrm{~h}$ exposure at $1100{ }^{\circ} \mathrm{C}$ upon the thermometers may be judged from the results presented in tables 3-10. Changes in derived values can be ob- served, and the group of thermometers as a whole tends to exhibit a downward drift in resistance ratio upon exposure (see tables 3 and 7). The results in table 7 show average changes for the group as a whole to be equivalent to $10.4 \mathrm{mK}$ at the gold point, $12.3 \mathrm{mK}$ at the silver point, and $8.4 \mathrm{mK}$ at the aluminum point after the $100 \mathrm{~h}$ exposure. A comparison of the results in table 6 and 8 , based on run 1 "calibration coefficients," shows an increase in the variability of extrapolated values of $t^{\prime}$ after the exposure.

However, the thermometers are apparently not degraded in their ability to measure values on the designated "temperature scale" because of the exposure, as shown by a comparison of the statistics for run 1 and run 2 in table 6. Upon "recalibration" at the tin and zinc points, the mean extrapolated values of $t$ ' at the gold, silver, and aluminum points in run 2 differ little from the values obtained in run 1; the differences are 4.1, 5.7, and $2.3 \mathrm{mK}$ respectively. Similarly, the statistics in table 9 show a change of only $2.1 \mathrm{mK}$ in the mean value of $t^{\prime \prime}$ at the silver point. As to thermometer variability, the statistics show the variability of $t^{\prime}$, after recalibration, actually to be less in run 2 than in run 1 . This is attributed more to a somewhat better precision in measurements in run 2 than to an effect of the exposure. Table 10 shows little difference in the variability of $R_{(}(\mathrm{TP})$ due to exposure. 

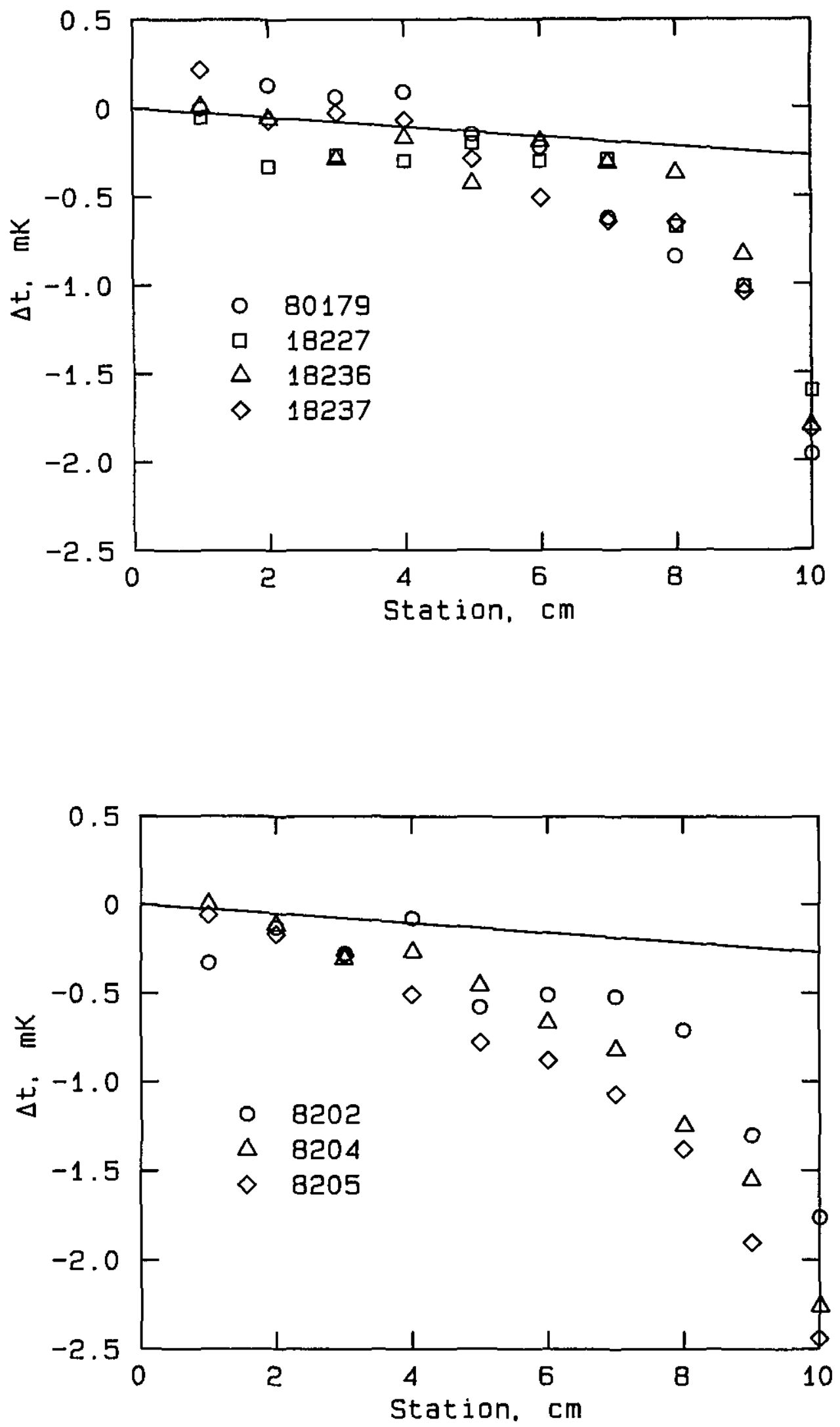

Figure 9-Effect of immersion in zinc cell at the freezing point, NIM thermometers, plotted from the data in table A3a. "Station" is the vertical location of the thermometer in the cell well; it represents the elevation of the thermometer, in $\mathrm{cm}$, above full immersion. The thermometer is fully immersed and resting on the bottom of the cell well at station $0 . \Delta t$ is the temperature equivalent of the difference in thermometer resistance, measured when the thermometer is fully immersed at station 0 and when it is elevated to the indicated station. The straight line represents the expected temperature gradient due to the hydrostatic pressure of the liquid zinc.

Figure 10-Effect of immersion in zinc cell at the freezing point, NBS thermometers, plotted from the data in table A3b. "Station" is the vertical location of the thermometer in the cell well; it represents the elevation of the thermometer, in $\mathrm{cm}$, above full immersion. The thermometer is fully immersed and resting on the bottom of the cell well at station $0 . \Delta t$ is the temperature equivalent of the difference in thermometer resistance, measured when the thermometer is fully immersed at station 0 and when it is elevated to the indicated station. The straight line represents the expected temperature gradient due to the hydrostatic pressure of the liquid zinc. 


\subsection{Short-Time Stability upon Temperature Cycling}

The short-time stability of a thermometer subjected to the temperature cycling of either run in the first experiment, which is assumed to be typical for a thermometer calibration procedure, may be partially assessed from variations in the thermometer resistance at the triple point of water. The results are given in table 10. The variability of resistance ratios will depend in part on the variability of $R(\mathrm{TP})$, since a resistance ratio is derived from the mean of before and after $R(\mathrm{TP})$ determinations. Thus, the root-mean-square variations of $R$ (TP) given in the table could be expected to contribute the following temperature equivalents to the standard deviation of a determination of $W(\mathrm{FP}): 0.9$ to $2.7 \mathrm{mK}$ at the gold point, 0.8 to $2.4 \mathrm{mK}$ at the silver point, 0.6 to $1.7 \mathrm{mK}$ at the aluminum point.

\subsection{Temperature Coefficient of Resistance}

The high values of the alpha coefficient given in table 4 show that the platinum in all of the thermometers is very pure and in a well defined physical state. The changes in alpha coefficients produced by the $100 \mathrm{~h}$ exposure at $1100^{\circ} \mathrm{C}$ are consistent with the changes observed in resistance ratios at the fixed points.

\subsection{Immersion Characteristics}

The results of the third experiment provide some information about thermometer immersion characteristics. It must be emphasized that immersion behavior depends not only on thermometer characteristics, but also on details of the environment surrounding the thermometer. Figures 9 and 10 show the immersion behavior of the thermometers in the zinc cell.

The set of NIM thermometers appears to "track" the temperature gradient produced by hydrostatic pressure over the bottom $4 \mathrm{~cm}$ of immersion, while the set of NBS thermometers probably tracks the gradient over the bottom $2 \mathrm{~cm}$ of immersion. Consequently, immersion losses at the zinc point are probably not a major source of error in the temperature determinations with any of the thermometers. While it is believed that immersion losses at other fixed points used in the experiments are not a limiting source of error, a more thorough examination of thermometer immersion behavior in all of the fixed-point cells would be highly desirable, if measurements could be made with adequate precision (see below).

\subsection{Heating Effect of Measuring Current}

Heating effects at all fixed points are listed in tables Ata through A1g. It may be noted that the heating effect in the NIM thermometers due to the $4 \mathrm{~mA}$ measuring current is small and almost negligible. The larger heating effect in the NBS thermometers (and also the poorer immersion characteristic noted above) is attributable to resistor design; half the resistor wire is remote from the wall of the thermometer sheath in the toroidal resistor.

\subsection{Electrical Leakage of Thermometer Supporting Parts}

The results of the second experiment, plotted in figures 3 through 8 , provide some information about the effects of electrical leakage in the thermometers. The experiment takes advantage of the electrical guard driving circuit available in the automatic bridge used. The internal guard system in the guarded lead thermometers (NBS) reduces the error due to electrical leakage from lead to lead in the thermometer, and from the thermometer leads to the bridge through ground. It does not, however, prevent leakage at the unguarded resistor. The external guard temporarily installed on the thermometers reduces only the effects due to leakage through ground between the thermometer and the grounded bridge.

It is evident from the data that leakage through ground is a major source of error in all of the thermometers when they are measured with a grounded instrument, and that the internal guard system used only partially eliminates the error. Without any guarding, leakage effects at the silver point can amount to $20 \mathrm{mK}$ or more. In other preliminary tests with internally guarded thermometers, it has been found that the effect is even greater at the gold point, but may be very small at the aluminum point. The data do not reveal whether the external guard completely eliminates the leakage through ground.

The data show that the effect can vary considerably from thermometer to thermometer. The effect may also vary from time to time in a particular thermometer. It has been observed that in some thermometers, in the absence of an external guard, a small movement of the thermometer during measurement in a high temperature fixed-point cell can alter the electrical leakage. The effect thus adds to the imprecision of measurements, and, in experiments such as immersion tests in the cells, may obscure results. 


\subsection{Thermometer Durability}

The thermometers experienced no catastrophic failures and no obvious mechanical degradation during the course of the experiments. The bending of support blades in two of the NIM thermometers and the separation of a lead in one of the NBS thermometers during initial stabilization suggest potential problem areas in the two designs.

\subsection{Agreement Among Thermometers of Derived Temperature Values}

The agreement among thermorneters has been tested by means of two "temperature scales." For one scale, on which values of temperature are designated by the symbol $t$ ", the thermometers are "calibrated" at the tin and zinc points, and then the values of temperature are determined at the aluminum, silver, and gold points by extrapolation. For the other scale, on which the thermometers are "calibrated" at the aluminum and gold points, the values of temperature (designated by the symbol $t$ ") at the silver point are determined by interpolation. These procedures allow comparison of derived values at the available constant-temperature fixed points, and the measures of variability given in tables 6 and 9 describe the agreement among thermometers using the procedures.

It is unlikely that a practical temperature scale at high temperatures would be defined by extrapolation from lower temperatures, as in the case of the " $t$ ' scale." Such a procedure exaggerates the variability in derived temperature values due to propagation of normal and unavoidable calibration errors. It is more likely that a practical scale will be devised so that values of temperature can be derived by interpolation between adjacent defi. ning fixed points, as in the case of the " $t$ " scale". Table 9 shows a smaller variability in $t^{\prime \prime}$ at the silver point (an interpolated value) than is shown in table 6 for $t^{\prime}$ at the silver point (an extrapolated value). A practical temperature scale utilizing all of the fixed points, including the silver point, could be expected to exhibit even less variability in derived temperature values. Therefore, the variations among thermometers reported here are larger than would be expected with the use of a well-designed temperature scale; the variations should be considered as upper bounds on thermometer variability.

Despite its limitations, the " $t$ ' scale" is useful for comparison purposes because of its simplicity and because the data necessary for deriving values on it are often available. In the present case, it reveals little difference between the two groups of thermometers, and in fact, all seven thermometers may be considered as a single set. It is interesting to compare these results with results obtained earlier using other sets of thermometers. This is done in table 11, where the results obtained with 2.5-ohm guarded-lead thermometers measured with the grounded automatic bridge [3], and the results obtained with 0.25 -ohm unguarded "birdcage" thermometers measured with isolated dc instrumentation [11], are summarized along with the present results. The summary shows differences between mean values at the fixed points that may be attributable, at least in part, to leakage problems. The summary also shows a decreasing variability in measurements in the past decade, though the decrease is not very dramatic.

Table 11. Statistics of $t^{\prime}$ at fixed points.

\begin{tabular}{|c|c|c|c|c|}
\hline RT set & & $\mathrm{AU}$ & AG & $\mathrm{AL}$ \\
\hline $\mathrm{NIM} / \mathrm{NBS}^{1}$ & Mean & 1062.5030 & 960.5233 & 660.4080 \\
\hline$(14 / 7)$ & $\mathrm{SD}^{4}$ & 0.0148 & 0.0097 & 0.0037 \\
\hline $1984^{\circ}$ & Range & 0.0485 & 0.0296 & 0.0149 \\
\hline NBS $2.5 \mathrm{ohm}^{2}$ & Mean & 1062.4898 & 960.5154 & 660.4127 \\
\hline$(11,16 / 8)$ & SD & 0.0114 & 0.0079 & 0.0024 \\
\hline 1982 & Range & 0.0341 & 0.0243 & 0.0088 \\
\hline Birdcage $^{3}$ & Mean & 1062.5308 & 960.5230 & $-\ldots$ \\
\hline$(27 / 9)$ & SD & 0.0191 & 0.0132 & $(0.0032)$ \\
\hline 1971 & Range & 0.0816 & 0.0541 & $(0.0087)$ \\
\hline
\end{tabular}

'NIM/NBS: 14 independent determinations at each of the fixed points with 7 thermometers, this report.

${ }^{2}$ NBS 2.5 ohm: $1 \mathrm{f}$ independent determinations at AU, 16 independent determinations at AG and AL with 8 thermometers, reported [3] in 1982.

${ }^{3}$ Birdcage: 27 independent determinations at $A U, A G$, and the antimony point with 9 thermometers, reported [11] in 1971 .

${ }^{4}$ SD: estimate of standard deviation of one value in indicated set.

\section{Summary and Conclusions}

The results of the experiments reported here show that the two sets of high-temperature platinum resistance thermometers tested, thermometers from different sources and of different design, behaved in a similar manner. The thermometers proved to be enough alike in their characteristics and performance that they could be considered as a single class.

It was found that upon prolonged exposure to high temperature the resistance ratios of the thermometers, on the average, changed by the equivalent of only 8 to $12 \mathrm{mK}$ at high temperature fixed points. The exposure $\left(100 \mathrm{~h}\right.$ at $\left.1100^{\circ} \mathrm{C}\right)$ was probably more severe than that to which thermometers would normally be subjected.

The thermometers were subjected to cycling between high temperatures and room temperature, comparable to cycling that would be encountered in normal use and 
calibration. The variability in thermometer resistance at the triple point of water with such cycling, expressed as a root-mean-square relative change in resistance per cycle, was found to range from about 1 to 3 parts in $10^{6}$. This variability in resistance is equivalent to temperature increments of 0.3 to $0.8 \mathrm{mK}$ at the triple point; it would contribute the equivalent of about 1 to $3 \mathrm{mk}$ to the variability of resistance ratios at the gold point derived from the mean of bracketing triple-point deter minations.

The thermometers proved to be durable; the $100-\mathrm{h}$ exposure produced no pronounced mechanical change in them, and throughout the tests their alpha coefficients remained greater than $0.0039268 \mathrm{~K}^{-1}$. Self-heating effects and immersion characteristics of the thermometers were found to be commensurate with thermometer design and not to be accuracy-limiting sources of error. When the thermometers were calibrated on a simple quadratic "temperature scale" and values determined by extrapolation to high temperatures, the standard deviation of a single thermometer measurement was estimated to be about $4 \mathrm{mK}$ at the aluminum point, $10 \mathrm{mK}$ at the silver point, and $15 \mathrm{mK}$ at the gold point. These values were found to compare favorably with values determined in the past by other sets of low resistance thermometers.

In contrast, it was found that electrical leakage through ground, between a thermometer at high temperature and a grounded measuring instrument, introduced large errors. Errors equivalent to $20 \mathrm{mK}$ or more were observed at the silver point, and even greater errors were indicated at the gold point. Internal guarding of thermometer leads only partially eliminated the leakage, while the use of an electrical guard outside the thermometer appeared to be more effective. Consequently, the results reported here are probably biased by errors due to leakage effects, and variations in the leakage have also probably contributed to measurement imprecision. Electrical leakage through ground is believed to be the single largest source of error in the experiments.

Despite the problems with electrical leakage, it may be concluded from the results of the experiments that the thermometers tested are as good as or better than other thermometers tested in the past. A prior assessment has placed an uncertainty of about $10 \mathrm{mK}$ on "state-of-the-art" resistance thermometer measurements up to the gold point [14]. In view of their exceptional long-time stability, agreement in derived temperature values, and other favorable characteristics, the present thermometers could be expected to perform equally as well, or better, if they were used so as to eliminate biases due to leakage.

\section{References}

[1] Ling Shankang; Zhang Guoquan; Li Ruisheng; Wang Zilin; Li Zhiran; Zhao Qi; and Li Xumo. The development of temperature standards at NIM of China, chapter in Temperature, its measurement and control in science and industry, Vol. 5, part 1. J. F. Schooley, ed.-in-chief. New York: American Institute of Physics; 1982. 191-195.

[2] Long Guang, and Tao Hongtt. Stability of precision high temperature platinum resistance thermometer, chapter in Temperature, its measurement and control in science and industry, Vol. 5, part 2. J. F. Schooley, ed.-in-chief. New York: American Institute of Physics; 1982. 783-787.

[3] Evans, J. P. Experiences with high-temperature platinum resistance thermometers, chapter in Temperature, its measurement and control in science and industry, Vol. 5, part 2. J. F. Schooley, ed.-in-chief. New York: American Institute of Physics; 1982. 771-781.

[4] Li Xumo; Zhang Jinde; Su Jinrong; and Chen Deming. A new high-temperature platinum resistance thermometer. Metrologia 18 (4): 203-208; 1982 December.

[5] Bass, N. Construction of the NBS-design high-ternperature platinum resistance thermometer, part 1 of Techniques in hightemperature resistance thermometry. Natl. Bur. Stand. (U.S.) Tech. Note 1183; 1984 January.

[6] Evans, J. P., and Tillett, S. B. Toroidal resistor for hightemperature phatinum resistance thermometers, part 2 of Techniques in high-temperature resistance thermometry. Natl. Bur. Stand. (U.S.) Tech. Note 1183; 1984 January.

[7] Berry, R. J. The iufluence of crystal defects in platinum on platinum resistance thermometry, chapter in Temperature, its measurement and control in science and industry, Vol. 4, part 2. Harmon H. Plumb, ed.-in-chief; L. G. Rubin, ed. Pittsburgh; Instrument Socjety of America; 1972. 937-949.

[8] Berry, R. J. Evaluation and control of platinum oxidation errors in standard platinum resistance thermometers, chapter in Temperature, its measurement and control in science and industry, Vol. 5, part 2. J. F. Schooley, ed--in-chief. New York: American Institute of Physics; 1982. 743-752.

[9] Evans, J. P., and D. M. Sweger. Immersion cooler for freezing ice mantles on triple-point-of-water cells. Rev. Sci. Instr. 40 (2): 376-377; 1969 February.

[10] Furukawa, G. T. Investigation of freezing temperature of National Bureau of Standards aluminum standards. J. Res. Natl. Bur. Stand. (U.S.) 78A (4): 477-495; 1974 July-August.

[11] Evans, J. P., and S. D. Wood. An intercomparison of high temperature platinum resistance thermometers and standard thermocouples. Metrologia 7 (3): 108-130; 1971 July.

[12] Cutkosky, R. D. An automatic resistance thermometer bridge. IEEE Trans. Instrum. Meas. IM-13 (4): 330-333; 1980 December.

[13] Cutkosky, R. D. Guarding techniques for resistance thermometers. IEEE Trans. Instrum. Meas. IM-30 (3): 217-220; 1981 September.

[14] Evans, J. P. High temperature platinum resistance thermometry, chapter in Temperature, its measurement and control in science and industry, Vol. 4, part 2. Harmon $\mathrm{H}$. Plumb, ed-in-chief; L. G. Rubin, ed. Pittsburgh: Instrument Society of America; 1972. 899-906. 


\section{APPENDIX}

Table A1a. Resistance of thermometer 80179 at fixed points.

\begin{tabular}{|c|c|c|c|c|c|c|c|c|}
\hline \multirow[b]{2}{*}{$\mathrm{FP}^{\prime}$} & \multicolumn{4}{|c|}{ Run 1} & \multicolumn{4}{|c|}{ Run 2} \\
\hline & $R(\mathrm{TP})^{2}$ & $R(\mathrm{FP})^{3}$ & & & $R(\mathrm{TP})$ & $R(\mathrm{FP})$ & & \\
\hline $\mathbf{T P}$ & 0.24354530 & & 10 & & 0.24355153 & & 23 & \\
\hline$A U$ & & 1.11338142 & & 17 & & 1.11339495 & & 30 \\
\hline TP & 0.24354484 & & 37 & & 0.24355032 & & 19 & \\
\hline$A G$ & & 1.04390980 & & 22 & & 1.04391980 & & 11 \\
\hline TP & 0.24354602 & & 10 & & 0.24355100 & & 4 & \\
\hline AL & & 0.82218768 & & 15 & & 0.82219719 & & 20 \\
\hline TP & 0.24354487 & & 19 & & 0.24355033 & & 1 & \\
\hline $\mathrm{ZN}$ & & 0.62563109 & & 15 & & 0.62563938 & & 9 \\
\hline$T P$ & 0.24354467 & & 22 & & 0.24355013 & & 8 & \\
\hline SN & & 0.46097202 & & 24 & & 0.46097844 & & 28 \\
\hline TP & 0.24354465 & & 16 & & 0.24354968 & & 14 & \\
\hline
\end{tabular}

${ }^{1}$ Measurements taken in order indicated.

${ }^{2} R$ (TP): thermometer resistance (ohms) at triple point of water for zero measuring current.

${ }^{3} R$ (FP): thermometer resistance (ohms) at indicated metal freezing point for zero measuring current.

${ }^{4} \mathrm{HE}(4)$ : increase in sesistance of thermometer (ohms $\times 10^{-8}$ ) due to heating effect of $4 \mathrm{~mA}$ measuring current.

Table A1b. Resistance of thermometer 18227 at fixed points.

\begin{tabular}{|c|c|c|c|c|c|c|c|c|}
\hline \multirow[b]{2}{*}{$\mathrm{FP}^{\prime}$} & \multicolumn{4}{|c|}{ Run 1} & \multicolumn{4}{|c|}{ Run 2} \\
\hline & $R(\mathrm{TP})^{2}$ & $R(\mathbf{F P})^{3}$ & & & $R(\mathbf{T P})$ & $R(\mathrm{FP})$ & & \\
\hline TP & 0.26036578 & & 17 & & 0.26036839 & & 23 & \\
\hline $\mathbf{A U}$ & & 1.19023546 & & 41 & & 1.19023032 & & 24 \\
\hline $\mathrm{TP}$ & 0.26036617 & & 8 & & 0.26036787 & & 29 & \\
\hline$A G$ & & 1.11596340 & & 14 & & 1.11595591 & & 6 \\
\hline TP & 0.26036605 & & 15 & & 0.26036834 & & 4 & \\
\hline A.L & & 0.87894006 & & 14 & & 0.87893466 & & 19 \\
\hline $\mathbf{T P}$ & 0.26036600 & & 27 & & 0.26036791 & & 11 & \\
\hline$Z \mathbf{N}$ & & 0.66881872 & & 38 & & 0.66881738 & & 6 \\
\hline TP & 0.26036586 & & 10 & & 0.26036793 & & 16 & \\
\hline $\mathrm{SN}$ & & 0.49279685 & & 26 & & 0.49279604 & & 24 \\
\hline TP & 0.26036652 & & 19 & & 0.26036836 & & 5 & \\
\hline
\end{tabular}

Table A1c. Resistance of thermometer 18236 at fixed points.

\begin{tabular}{|c|c|c|c|c|c|c|c|c|}
\hline \multirow[b]{2}{*}{$\mathrm{FP}^{1}$} & \multicolumn{4}{|c|}{ Run 1} & \multicolumn{4}{|c|}{ Run 2} \\
\hline & $R(\mathrm{TP})^{2}$ & $R(\mathrm{FP})^{3}$ & & $\mathrm{HE}(4)^{4}$ & $R(\mathrm{TP})$ & $R(\mathrm{FP})$ & & $\mathrm{HE}(4)$ \\
\hline $\mathrm{TP}$ & 0.25736827 & & 1 & & 0.25737145 & & 17 & \\
\hline $\mathrm{AU}$ & & 1.17651167 & & $3 B$ & & 1.17652127 & & 27 \\
\hline$T P$ & $0.2573695 \mathrm{t}$ & & 17 & & 0.25737131 & & 16 & \\
\hline$A G$ & & 1.10310634 & & 20 & & 1.10310718 & & 14 \\
\hline $\mathrm{TP}$ & 0.25736898 & & 21 & & 0.25737129 & & 18 & \\
\hline $\mathrm{AL}$ & & 0.86881563 & & 23 & & 0.86881446 & & 42 \\
\hline $\mathbf{T P}$ & 0.25736916 & & 10 & & 0.25737091 & & 17 & \\
\hline $\mathrm{ZN}$ & & 0.66111513 & & 26 & & 0.66111592 & & 14 \\
\hline $\mathbf{T P}$ & 0.25736839 & & 18 & & 0.25737114 & & 13 & \\
\hline $\mathrm{SN}$ & & 0.48712186 & & 19 & & 0.48712267 & & 24 \\
\hline$T P$ & 0.25736902 & & 4 & & 0.25737158 & & 11 & \\
\hline
\end{tabular}


Table A1d. Resistance of thermometer 18237 at fixed points.

\begin{tabular}{|c|c|c|c|c|c|c|c|c|}
\hline \multirow[b]{2}{*}{$\mathrm{FP}^{1}$} & \multicolumn{4}{|c|}{ Run 1} & \multicolumn{4}{|c|}{ Run 2} \\
\hline & $R(\mathbf{T P})^{2}$ & $R(F P)^{3}$ & & & $R(\mathrm{TP})$ & $R(\mathrm{FP})$ & & \\
\hline TP & 0.26271185 & & 20 & & 0.26271457 & & 0 & \\
\hline $\mathrm{AU}$ & & 1.20094154 & & 45 & & 1.20093838 & & 42 \\
\hline TP & 0.26271268 & & 5 & & 0.26271380 & & 7 & \\
\hline$A G$ & & 1.12601457 & & 23 & & 1.12600557 & & 14 \\
\hline$T P$ & 0.26271186 & & 16 & & 0.26271372 & & 2 & \\
\hline $\mathrm{AL}$ & & 0.88685765 & & 35 & & 0.88685013 & & 14 \\
\hline $\mathrm{TP}$ & 0.26271188 & & 14 & & 0.26271298 & & 18 & \\
\hline $\mathrm{ZN}$ & & 0.67484408 & & 23 & & 0.67483947 & & 20 \\
\hline $\mathrm{TP}$ & 0.26271194 & & 9 & & $0.2627130^{9}$ & & 19 & \\
\hline SN & & 0.49723614 & & 30 & & 0.49723423 & & 20 \\
\hline TP & 0.26271258 & & 4 & & 0.26271339 & & 10 & \\
\hline
\end{tabular}

Table A1e. Resistance of thermometer 8202 at fixed points.

\begin{tabular}{|c|c|c|c|c|c|c|c|c|}
\hline \multirow[b]{2}{*}{$F P^{1}$} & \multicolumn{4}{|c|}{ Run 1} & \multicolumn{4}{|c|}{ Run 2} \\
\hline & $R(\mathrm{TP})^{2}$ & $R(\mathrm{FP})^{3}$ & & & $R(\mathrm{TP})$ & $R(\mathrm{FP})$ & $\mathrm{HE}(4)$ & \\
\hline $\mathrm{TP}$ & 0.37344847 & & 82 & & 0.37345575 & & 77 & \\
\hline $\mathrm{AU}$ & & 1.70715643 & & 123 & & 1.70717762 & & 121 \\
\hline TP & 0.37344900 & & 72 & & 0.37345655 & & 87 & \\
\hline$A G$ & & 1.60063481 & & 87 & & 1.60065483 & & 89 \\
\hline TP & 0.37345106 & & 67 & & 0.37345562 & & 102 & \\
\hline AL & & 1.26069404 & & 98 & & 1.26070485 & & 100 \\
\hline $\mathbf{T P}$ & 0.37345126 & & 70 & & 0.37345654 & & 92 & \\
\hline $\mathrm{ZN}$ & & 0.95931356 & & 117 & & 0.95932446 & & 84 \\
\hline $\mathbf{T P}$ & 0.37345063 & & 84 & & 0.37345639 & & 84 & \\
\hline SN & & 0.70683891 & & 120 & & 0.70684723 & & 92 \\
\hline$T P$ & 0.37345157 & & 69 & & 0.37345619 & & 86 & \\
\hline
\end{tabular}

Table A1f. Resistance of thermometer 8204 at fixed points.

\begin{tabular}{|c|c|c|c|c|c|c|c|c|}
\hline \multirow[b]{2}{*}{$\mathbf{F P} \mathbf{P}^{\prime}$} & \multicolumn{4}{|c|}{ Run 1} & \multicolumn{4}{|c|}{ Run 2} \\
\hline & $R(\mathrm{TP})^{2}$ & $R(\mathbf{F P})^{3}$ & & & $R(\mathrm{TP})$ & $R(\mathrm{FP})$ & $H E(4)$ & \\
\hline $\mathrm{TP}$ & 0.36121077 & & 58 & & 0.36121424 & & 50 & \\
\hline $\mathbf{A U}$ & & 1.65121770 & & 97 & & 1.65124068 & & 86 \\
\hline $\mathbf{T P}$ & 0.36121028 & & 72 & & 0.36121557 & & 56 & \\
\hline$A G$ & & 1.54818827 & & 90 & & 1.54820525 & & 64 \\
\hline $\mathrm{TP}$ & 0.36121172 & & 55 & & 0.36121378 & & 65 & \\
\hline $\mathrm{AL}$ & & 1.21938181 & & 82 & & 1,21938917 & & 91 \\
\hline $\mathbf{T P}$ & 0.36121142 & & 6.6 & & 0.36121351 & & 64 & \\
\hline ZN & & 0.92787383 & & 94 & & 0.92787912 & & 104 \\
\hline $\mathrm{TP}$ & 0.36121198 & & 74 & & 0.36121466 & & 72 & \\
\hline SN & & 0.68367531 & & 88 & & 0.68367855 & & 102 \\
\hline TP & 0.36121282 & & 59 & & 0.36121529 & & 62 & \\
\hline
\end{tabular}


Table A1g. Resistance of thermometer 8205 at fixed points.

\begin{tabular}{|c|c|c|c|c|c|c|c|c|}
\hline \multirow[b]{2}{*}{$\mathrm{FP}^{1}$} & \multicolumn{4}{|c|}{ Run 1} & \multicolumn{4}{|c|}{ Run 2} \\
\hline & $R(\mathrm{TP})^{2}$ & $R(\mathrm{FP})^{3}$ & & & $R(\mathrm{TP})$ & $R(\mathbf{F P})$ & $\mathrm{HE}(4)$ & \\
\hline $\mathrm{TP}$ & 0.37777464 & & 77 & & 0.37777391 & & 94 & \\
\hline$A U$ & & 1.72588249 & & 105 & & 1.72688057 & & 103 \\
\hline $\mathrm{TP}$ & 0.37777472 & & 80 & & 0.37777600 & & 77 & \\
\hline$A G$ & & 1.61914245 & & 88 & & 1.61913827 & & 89 \\
\hline$T P$ & 0.37777384 & & 87 & & 0.37777615 & & 85 & \\
\hline$A L$ & & 1.27526979 & & 106 & & 1.27527344 & & 97 \\
\hline$T \mathbf{P}$ & 0.37777447 & & 89 & & 0.37777749 & & 62 & \\
\hline $\mathbf{Z N}$ & & 0.97040708 & & 124 & & 0.97041140 & & 102 \\
\hline $\mathbf{T P}$ & 0.37777487 & & 85 & & 0.37777686 & & 84 & \\
\hline $\mathbf{S N}$ & & 0.71501507 & & 117 & & 0.71501814 & & 111 \\
\hline $\mathbf{T P}$ & 0.37777526 & & 75 & & 0.37777734 & & 80 & \\
\hline
\end{tabular}

Table A2a. Effect of guarding at silver point, thermometer 80179.

\begin{tabular}{|c|c|c|c|c|c|}
\hline \multirow[t]{2}{*}{ No. ${ }^{1}$} & \multicolumn{2}{|c|}{ Thermometer resistance $^{2}$} & \multirow[t]{2}{*}{ No. } & \multicolumn{2}{|c|}{ Thermometer resistance } \\
\hline & $\begin{array}{l}\text { External } \\
\text { Guard }\end{array}$ & $\begin{array}{l}\text { No } \\
\text { Guard }\end{array}$ & & $\begin{array}{l}\text { External } \\
\text { Guard }\end{array}$ & $\begin{array}{l}\text { No } \\
\text { Guard }\end{array}$ \\
\hline 1 & 1.04392444 & & 31 & 1.04392563 & \\
\hline 2 & 1.04392494 & & 32 & 1.04392576 & \\
\hline 3 & 1.04392533 & & 33 & 1.04392585 & \\
\hline 4 & 1.04392506 & & 34 & & 1.04392155 \\
\hline 5 & 1.04392526 & & 35 & & 1.04392162 \\
\hline 6 & & 1.04392090 & 36 & 1.04392582 & \\
\hline 7 & & 1.04392092 & 37 & 1.04392580 & \\
\hline 8 & 1.04392524 & & 38 & 1.04392595 & \\
\hline 9 & 1.04392531 & & 39 & 1.04392578 & \\
\hline 10 & 1.04392552 & & 40 & 1.04392577 & \\
\hline 11 & 1.04392542 & & 41 & & 1.04392101 \\
\hline 12 & 1.04392569 & & 42 & & 1.04392163 \\
\hline 13 & & 1.04392100 & 43 & 1.04392580 & \\
\hline 14 & & 1.04392127 & 44 & 1.04392567 & \\
\hline 15 & 1.04392567 & & 45 & 1.04392564 & \\
\hline 16 & 1.04392553 & & 46 & 1.04392575 & \\
\hline 17 & 1.04392556 & & 47 & 1.04392592 & \\
\hline 18 & 1.04392541 & & 48 & & 1.04392127 \\
\hline 19 & 1.04392538 & & 49 & & 1.04392115 \\
\hline 20 & & 1.04392126 & 50 & 1.04392502 & \\
\hline 21 & & 1.04392155 & 51 & 1.04392489 & \\
\hline 22 & 1.04392592 & & 52 & 1.04392467 & \\
\hline 23 & 1.04392583 & & 53 & 1.04392454 & \\
\hline 24 & 1.04392610 & & 54 & 1.04392402 & \\
\hline 25 & 1.04392569 & & 55 & & 1.04391980 \\
\hline 26 & 1.04392554 & & 56 & & 1.04391904 \\
\hline 27 & & 1.04392194 & 57 & 1.04392274 & \\
\hline 28 & & 1.04392176 & 58 & 1.04392240 & \\
\hline 29 & 1.04392554 & & 59 & 1.04392180 & \\
\hline 30 & 1.04392560 & & 60 & 1.04392091 & \\
\hline
\end{tabular}

${ }^{1}$ No: sequence number of reading. Resistance determinations made at 5 min intervals.

${ }^{2}$ All determinations made with normal measuring current. 
Table A2b. Effect of guarding at silver point, thermometer 18236 .

\begin{tabular}{|c|c|c|c|c|c|}
\hline \multirow[t]{2}{*}{ No. ${ }^{1}$} & \multicolumn{2}{|c|}{ Thermometer resistance ${ }^{2}$} & \multirow[t]{2}{*}{ No. } & \multicolumn{2}{|c|}{ Thermometer resistance } \\
\hline & $\begin{array}{l}\text { External } \\
\text { Guard }\end{array}$ & $\begin{array}{l}\text { No } \\
\text { Guard }\end{array}$ & & $\begin{array}{l}\text { External } \\
\text { Guard " }\end{array}$ & $\begin{array}{l}\text { No } \\
\text { Guard }\end{array}$ \\
\hline 1 & 1.10310830 & & 36 & 1.10310753 & \\
\hline 2 & 1.10310798 & & 37 & 1.10310762 & \\
\hline 3 & 1.10310787 & & 38 & 1.10310730 & \\
\hline 4 & 1.10310773 & & 39 & 1.10310727 & \\
\hline 5 & 1.10310780 & & 40 & & 1.10309795 \\
\hline 6 & 1.10310777 & & 41 & 1.10310717 & \\
\hline 7 & 1.10310766 & & 42 & 1.10310708 & \\
\hline$B$ & 1.10310783 & & 43 & 1.10310663 & \\
\hline 9 & 1.10310764 & & 44 & 1.10310644 & \\
\hline 10 & & 1.10309809 & 45 & & 1.10309621 \\
\hline 11 & 1.10310763 & & 46 & 1.10310619 & \\
\hline 12 & 1.10310782 & & 47 & 1.10310571 & \\
\hline 13 & 1.10310777 & & 48 & 1.10310504 & \\
\hline 14 & 1.10310757 & & 49 & 1.10310429 & \\
\hline 15 & 1.10310767 & & 50 & & 1.10309304 \\
\hline 16 & & 1.10309847 & 51 & 1.10310223 & \\
\hline 17 & 1.10310786 & & 52 & 1.10310018 & \\
\hline 18 & 1.10310796 & & 53 & 1.10309737 & \\
\hline 19 & 1.10310766 & & 54 & 1.10309643 & \\
\hline 20 & & 1.10309836 & 55 & 1.10309299 & \\
\hline 21 & 1.10310790 & & 56 & $1.103087 \mathrm{Bg}$ & \\
\hline 22 & 1.10310762 & & 57 & 1.10307519 & \\
\hline 23 & 1.10310756 & & 58 & 1.10300411 & \\
\hline 24 & 1.10310779 & & 59 & 1.10234670 & \\
\hline 25 & & 1.10309850 & 60 & 1.10218298 & \\
\hline 26 & 1.10310748 & & 61 & 1.10208952 & \\
\hline 27 & 1.10310777 & & 62 & 1.10228282 & \\
\hline 28 & l. 10310760 & & 63 & 1.10229746 & \\
\hline 29 & 1.10310764 & & 64 & 1.10229948 & \\
\hline 30 & & 1.10309806 & 65 & 1.10228864 & \\
\hline 31 & & 1.10309806 & 66 & 1.10227829 & \\
\hline 32 & 1.10310766 & & 67 & 1.10225154 & \\
\hline 33 & 1.10310748 & & 68 & 1.10226344 & \\
\hline 34 & 1.10310761 & & 69 & 1.10225939 & \\
\hline 35 & & 1.10309818 & 70 & 1.10224858 & \\
\hline
\end{tabular}

Table A2c. Effect of guarding at silver point, thermometer 18237.

\begin{tabular}{|c|c|c|c|c|c|}
\hline \multirow[t]{2}{*}{ No. ${ }^{1}$} & \multicolumn{2}{|c|}{ Thermometer resistance ${ }^{2}$} & \multirow[t]{2}{*}{ No. } & \multicolumn{2}{|c|}{ Thermometer resistance } \\
\hline & $\begin{array}{l}\text { External } \\
\text { Guard }\end{array}$ & $\begin{array}{l}\text { No } \\
\text { Guard }\end{array}$ & & $\begin{array}{l}\text { External } \\
\text { Guard }\end{array}$ & $\begin{array}{l}\text { No } \\
\text { Guard }\end{array}$ \\
\hline 1 & 1.12601866 & & 13 & 1.12601706 & \\
\hline 2 & 1.12601772 & & 14 & 1.12601735 & \\
\hline 3 & 1.12601741 & & 15 & & 1.12600610 \\
\hline 4 & 1.12601719 & & 16 & 1.12601762 & \\
\hline 5 & 1.12601699 & & 17 & 1.12601739 & \\
\hline 6 & 1.12601702 & & 18 & 1.12601746 & \\
\hline 7 & 1.12601732 & & 19 & 1.12601757 & \\
\hline 8 & 1.12601692 & & 20 & 1.12601742 & \\
\hline 9 & 1.12601711 & & 21 & & $1 . \$ 2600639$ \\
\hline 10 & & 1.12600623 & 22 & 1.12601775 & \\
\hline 11 & 1.12601713 & & 23 & 1.12601739 & \\
\hline 12 & 1.12601717 & & 24 & 1.12601781 & \\
\hline
\end{tabular}


Table A2c. Effect of guarding at silver point, thermometer 18237.-Continued

\begin{tabular}{|c|c|c|c|c|c|}
\hline \multirow[t]{2}{*}{ No. ${ }^{1}$} & \multicolumn{2}{|c|}{ Thermometer resistance ${ }^{2}$} & \multirow[t]{2}{*}{ No. } & \multicolumn{2}{|c|}{ Thermometer resistance } \\
\hline & $\begin{array}{l}\text { External } \\
\text { Guard }\end{array}$ & $\begin{array}{l}\text { No } \\
\text { Guard }\end{array}$ & & $\begin{array}{l}\text { External } \\
\text { Guard }\end{array}$ & $\begin{array}{l}\text { No } \\
\text { Guard }\end{array}$ \\
\hline 25 & & 1.12600647 & 49 & 1.12601716 & \\
\hline 26 & 1.12601744 & & 50 & & 1.12600598 \\
\hline 27 & 1.12601768 & & 51 & 1.12601704 & \\
\hline 28 & 1.12601773 & & 52 & 1.12601684 & \\
\hline 29 & 1.12601745 & & 53 & 1.12601655 & \\
\hline 30 & & 1.12600659 & 54 & 1.12601641 & \\
\hline 31 & 1.12601764 & & 55 & 1.12601612 & \\
\hline 32 & 1.12601779 & & 56 & 1.12601584 & \\
\hline 33 & 1.12601781 & & 57 & 1.12601543 & \\
\hline 34 & 1.12601807 & & 58 & 1.12601487 & \\
\hline 35 & & 1.12600667 & 59 & 1.12601409 & \\
\hline 36 & 1.12601779 & & 60 & 1.12601322 & \\
\hline 37 & 1.12601796 & & 61 & 1.12601211 & \\
\hline 38 & 1.12601778 & & 62 & 1.12601112 & \\
\hline 39 & 1.12601790 & & 63 & 1.12601050 & \\
\hline 40 & & 1.12600662 & 64 & 1.12600944 & \\
\hline 41 & 1.12601752 & & 65 & 1.12600784 & \\
\hline 42 & 1.12601792 & & 66 & 1.12600536 & \\
\hline 43 & 1.12601777 & & 67 & 1.12600135 & \\
\hline 44 & 1.12601760 & & 68 & 1.12599782 & \\
\hline 45 & & 1.12600655 & 69 & 1.12599122 & \\
\hline 46 & 1.12601740 & & 70 & 1.12597467 & \\
\hline 47 & 1.12601745 & & 71 & 1.12561508 & \\
\hline 48 & 1.12601774 & & 72 & 1.12534593 & \\
\hline
\end{tabular}

Table A2d. Effect of guarding at silver point, thermometer 8202.

\begin{tabular}{|c|c|c|c|c|c|c|c|c|c|}
\hline \multirow[t]{2}{*}{ No. ${ }^{1}$} & \multicolumn{4}{|c|}{ Thermometer resistance ${ }^{2}$} & \multirow[t]{2}{*}{ No. } & \multicolumn{4}{|c|}{ Thermometer resistance } \\
\hline & $\begin{array}{l}\text { Both } \\
\text { Guards }\end{array}$ & $\begin{array}{l}\text { External } \\
\text { Guard }\end{array}$ & $\begin{array}{l}\text { Internal } \\
\text { Guard }\end{array}$ & $\begin{array}{l}\text { No } \\
\text { Guard }\end{array}$ & & $\begin{array}{l}\text { Both } \\
\text { Guards }\end{array}$ & $\begin{array}{l}\text { External } \\
\text { Guard }\end{array}$ & $\begin{array}{l}\text { Internal } \\
\text { Guard }\end{array}$ & $\begin{array}{l}\text { No } \\
\text { Guard }\end{array}$ \\
\hline 1 & 1.60064788 & & & & 25 & & & & 1.60063539 \\
\hline 2 & 1.60064955 & & & & 26 & 1.60065087 & & & \\
\hline 3 & 1.60065002 & & & & 27 & 1.60065094 & & & \\
\hline 4 & 1.60065063 & & & & 28 & 1.60065082 & & & \\
\hline 5 & 1.60065065 & & & & 29 & 1.60065076 & & & \\
\hline 6 & 1.60065069 & & & & 30 & 1.60065037 & & & \\
\hline 7 & & 1.60064992 & & & 31 & & 1.60064967 & & \\
\hline 8 & & & 1.60064424 & & 32 & & & 1.60064438 & \\
\hline 9 & & & & 1.60063572 & 33 & & & & 1.60063516 \\
\hline 10 & 1.60065077 & & & & 34 & 1.60065044 & & & \\
\hline 11 & 1.60065091 & & & & 35 & 1.60065075 & & & \\
\hline 12 & 1.60065091 & & & & 36 & 1.60065028 & & & \\
\hline 13 & 1.60065105 & & & & 37 & 1.60065012 & & & \\
\hline 14 & 1.60065082 & & & & 38 & 1.60065039 & & & \\
\hline 15 & & 1.60064994 & & & 39 & & 1.60064949 & & \\
\hline 16 & & & 1.60064455 & & 40 & & & 1.60064320 & \\
\hline 17 & & & & 1.60063609 & 41 & & & & 1.60063464 \\
\hline 18 & 1.60065083 & & & & 42 & 1.60065000 & & & \\
\hline 19 & 1.60065093 & & & & 43 & 1.60064946 & & & \\
\hline 20 & 1.60065089 & & & & 44 & 1.60064935 & & & \\
\hline 21 & 1.60065073 & & & & 45 & 1.60064951 & & & \\
\hline 22 & 1.60065092 & & & & 46 & 1.60064924 & & & \\
\hline 23 & & 1.60064983 & & & 47 & & 1.60064788 & & \\
\hline 24 & & & 1.60064400 & & 48 & & & 1.60064197 & \\
\hline
\end{tabular}


Table A2d. Effect of guarding at silver point, thermometer 8202.-Continued

\begin{tabular}{|c|c|c|c|c|c|c|c|c|c|}
\hline \multirow[t]{2}{*}{ No. ${ }^{1}$} & \multicolumn{4}{|c|}{ Thermometer resistance ${ }^{2}$} & \multirow[t]{2}{*}{ No. } & \multicolumn{4}{|c|}{ Thermometer resistance } \\
\hline & $\begin{array}{l}\text { Both } \\
\text { Guards }\end{array}$ & $\begin{array}{l}\text { External } \\
\text { Guard }\end{array}$ & $\begin{array}{l}\text { Internal } \\
\text { Guard }\end{array}$ & $\begin{array}{l}\text { No } \\
\text { Guard }\end{array}$ & & $\begin{array}{l}\text { Both } \\
\text { Guards }\end{array}$ & $\begin{array}{l}\text { External } \\
\text { Guard }\end{array}$ & $\begin{array}{l}\text { Internal } \\
\text { Guard }\end{array}$ & $\begin{array}{l}\text { No } \\
\text { Guard }\end{array}$ \\
\hline 49 & & & & 1.60063237 & 52 & 1.60064660 & & & \\
\hline 50 & 1.60064810 & & & & 53 & 1.60064631 & & & \\
\hline 51 & 1.60064700 & & & & 54 & 1.60064501 & & & \\
\hline
\end{tabular}

1,2 See footnote of Table A2a.

Tahle A2e. Effect of guarding at silver point, thermometer 8204 .

\begin{tabular}{|c|c|c|c|c|c|c|c|c|c|}
\hline \multirow[t]{2}{*}{ No. } & \multicolumn{4}{|c|}{ Thermometer resistance ${ }^{2}$} & \multirow[t]{2}{*}{ No. } & \multicolumn{4}{|c|}{ Thermometer resistancè } \\
\hline & $\begin{array}{l}\text { Both } \\
\text { Guards } \\
\end{array}$ & $\begin{array}{l}\text { External } \\
\text { Guard }\end{array}$ & $\begin{array}{l}\text { Internal } \\
\text { Guard }\end{array}$ & $\begin{array}{l}\text { No } \\
\text { Guard }\end{array}$ & & $\begin{array}{l}\text { Both } \\
\text { Guards }\end{array}$ & $\begin{array}{l}\text { External } \\
\text { Guard }\end{array}$ & $\begin{array}{l}\text { Internal } \\
\text { Guard }\end{array}$ & $\begin{array}{l}\text { No } \\
\text { Guard }\end{array}$ \\
\hline 1 & 1.54820421 & & & & 30 & 1.54821341 & & & \\
\hline 2 & 1.54821086 & & & & 31 & 1.54821373 & & & \\
\hline 3 & 1.54821266 & & & & 32 & & 1.54821351 & & \\
\hline 4 & 1.54821332 & & & & 33 & & & 1.54821288 & \\
\hline 5 & 1.54821325 & & & & 34 & & & & 1.54821089 \\
\hline 6 & 1.54821350 & & & & 35 & 1.54821369 & & & \\
\hline 7 & 1.54821376 & & & & 36 & 1.54821357 & & & \\
\hline 8 & & 1.54821392 & & & 37 & 1.54821368 & & & \\
\hline 9 & & & 1.54821365 & & 38 & 1.54821359 & & & \\
\hline 10 & & & & 1.54821185 & 39 & 1.54821371 & & & \\
\hline 11 & 1.54821378 & & & & 40 & & 1.54821286 & & \\
\hline 12 & 1.54821371 & & & & 41 & & & $1.548212 B 7$ & \\
\hline 13 & 1.54821390 & & & & 42 & & & & 1.54821059 \\
\hline 14 & 1.54821361 & & & & 43 & 1.54821350 & & & \\
\hline 15 & 1.54821382 & & & & 44 & 1.54821356 & & & \\
\hline 16 & & 1.54821381 & & & 45 & 1.54821305 & & & \\
\hline 17 & & & 1.54821318 & & 46 & 1.54821356 & & & \\
\hline 18 & & & & 1.54821116 & 47 & 1.54821293 & & & \\
\hline 19 & 1.54821386 & & & & 48 & & 1.54821328 & & \\
\hline 20 & 1.54821364 & & & & 49 & & & 1.54821270 & \\
\hline 21 & 1.54821367 & & & & 50 & & & & 1.54821020 \\
\hline 22 & 1.54821375 & & & & 51 & 1.54821312 & & & \\
\hline 23 & 1.54821354 & & & & 52 & 1.54821318 & & & \\
\hline 24 & & 1.54821355 & & & 53 & 1.54821301 & & & \\
\hline 25 & & & 1.54821331 & & 54 & 1.54821318 & & & \\
\hline 26 & & & & $1.5482110 B$ & 55 & 1.54821297 & & & \\
\hline 27 & 1.54821401 & & & & 56 & 1.54821306 & & & \\
\hline 28 & 1.54821376 & & & & 57 & 1.54821263 & & & \\
\hline 29 & 1.54821373 & & & & 58 & 1.54821261 & & & \\
\hline
\end{tabular}

1,2 See footnotes of Table A2a.

Table A2f. Effect of guarding at silver point, thermometer $\$ 205$.

\begin{tabular}{|c|c|c|c|c|c|c|c|c|c|}
\hline \multirow[t]{2}{*}{ No.' } & \multicolumn{4}{|c|}{ Thermometer resistance ${ }^{2}$} & \multirow[t]{2}{*}{ No. } & \multicolumn{4}{|c|}{ Thermometer resistance } \\
\hline & $\begin{array}{l}\text { Both } \\
\text { Guards }\end{array}$ & $\begin{array}{l}\text { External } \\
\text { Guard }\end{array}$ & $\begin{array}{l}\text { Internal } \\
\text { Guard }\end{array}$ & $\begin{array}{l}\text { No } \\
\text { Guard }\end{array}$ & & $\begin{array}{l}\text { Both } \\
\text { Guards }\end{array}$ & $\begin{array}{l}\text { External } \\
\text { Guard }\end{array}$ & $\begin{array}{l}\text { Internal } \\
\text { Guard }\end{array}$ & $\begin{array}{l}\text { No } \\
\text { Guard }\end{array}$ \\
\hline 1 & 1.61914472 & & & & 9 & & & 1.61914954 & \\
\hline 2 & 1.61915280 & & & & 10 & & & & 1.61914129 \\
\hline 3 & 1.61915553 & & & & 11 & 1.61915803 & & & \\
\hline 4 & 1.61915653 & & & & 12 & 1.61915813 & & & \\
\hline 5 & 1.61915731 & & & & 13 & 1.61915796 & & & \\
\hline 6 & 1.61915743 & & & & 14 & 1.61915798 & & & \\
\hline 7 & 1.61915755 & & & & 15 & 1.61915860 & & & \\
\hline 8 & & 1.61915587 & & & 16 & & 1.61915636 & & \\
\hline
\end{tabular}


Table A2f. Effect of guarding at silver point, thermometer 8205.-Continued

\begin{tabular}{|c|c|c|c|c|c|c|c|c|c|}
\hline \multirow[t]{2}{*}{ No. ${ }^{1}$} & \multicolumn{4}{|c|}{ Thermometer resistance ${ }^{2}$} & \multirow[t]{2}{*}{ No. } & \multicolumn{4}{|c|}{ Thermometer resistance } \\
\hline & $\begin{array}{l}\text { Both } \\
\text { Guards }\end{array}$ & $\begin{array}{l}\text { External } \\
\text { Guard }\end{array}$ & $\begin{array}{l}\text { Internal } \\
\text { Guard }\end{array}$ & $\begin{array}{l}\text { No } \\
\text { Guard }\end{array}$ & & $\begin{array}{l}\text { Both } \\
\text { Guards }\end{array}$ & $\begin{array}{l}\text { External } \\
\text { Guard }\end{array}$ & $\begin{array}{l}\text { Internal } \\
\text { Guard }\end{array}$ & $\begin{array}{l}\text { No } \\
\text { Guard }\end{array}$ \\
\hline 17 & & & 1.61914904 & & 38 & 1.61915773 & & & \\
\hline 18 & & & & 1.61914080 & 39 & 1.61915751 & & & \\
\hline 19 & 1.61915808 & & & & 40 & & 1.61915609 & & \\
\hline 20 & 1.61915782 & & & & 41 & & & 1.61914825 & \\
\hline 21 & 1.61915787 & & & & 42 & & & & 1.61913994 \\
\hline 22 & 1.61915749 & & & & 43 & 1.61915756 & & & \\
\hline 23 & 1.61915748 & & & & 44 & 1.61915748 & & & \\
\hline 24 & & 1.61915669 & & & 45 & 1.61915719 & & & \\
\hline 25 & & & 1.61914880 & & 46 & 1.61915722 & & & \\
\hline 26 & & & & 1.61914080 & 47 & 1.61915693 & & & \\
\hline 27 & 1.61915787 & & & & 48 & 1.61915708 & & & \\
\hline 28 & 1.61915801 & & & & 49 & 1.61915726 & & & \\
\hline 29 & 1.61915779 & & & & 50 & 1.61915712 & & & \\
\hline 30 & 1.61915791 & & & & $5 i$ & 1.61915721 & & & \\
\hline 31 & 1.61915779 & & & & 52 & 1.61915681 & & & \\
\hline 32 & & 1.61915617 & & & 53 & 1.61915736 & & & \\
\hline 33 & & & 1.61914839 & & 54 & 1.61915669 & & & \\
\hline 34 & & & & 1.61914015 & 55 & 1.61915660 & & & \\
\hline 35 & 1.61915767 & & & & 56 & 1.61915658 & & & \\
\hline 36 & 1.61915781 & & & & 57 & 1.61915638 & & & \\
\hline 37 & 1.61915745 & & & & 58 & 1.61915644 & & & \\
\hline
\end{tabular}

Table A3a. Immersion characteristics of thermometers in zinc cell. ${ }^{1,3}$

\begin{tabular}{|c|c|c|c|c|c|c|c|c|c|}
\hline \multicolumn{2}{|c|}{ Station $^{2}$} & \multicolumn{3}{|c|}{ Resistance of thermometer number } & \multicolumn{2}{|c|}{ Station } & \multicolumn{3}{|c|}{ Resistance of thermometer number } \\
\hline $\mathrm{cm}$ & 80179 & 18227 & 18236 & 18237 & $\mathrm{~cm}$ & 80179 & 18227 & 18236 & 18237 \\
\hline 0 & 0.62564094 & 0.66881727 & 0.66111506 & 0.67483970 & 7 & 0.62563817 & 0.66881563 & 0.66111550 & 0.67483869 \\
\hline 0 & 0.62564009 & 0.66881635 & 0.66111560 & 0.67483926 & 6 & 0.62563851 & 0.66881562 & 0.66111561 & 0.67483881 \\
\hline 0 & 0.62563969 & 0.66881612 & 0.66111562 & 0.67483920 & 0 & 0.62563869 & 0.66881598 & 0.66111585 & 0.67483930 \\
\hline 0 & 0.62563923 & 0.66881629 & 0.66111546 & 0.67483921 & 0 & 0.62563858 & 0.66881588 & 0.66111580 & 0.67483918 \\
\hline 18 & 0.62469878 & 0.66772854 & 0.65999691 & 0.67377628 & 0 & 0.62563850 & 0.66881599 & 0.66111593 & 0.67483931 \\
\hline 18 & 0.62468420 & 0.66769737 & 0.65997147 & 0.67371738 & 5 & 0.62563830 & 0.66881572 & 0.66111552 & 0.67483899 \\
\hline 16 & 0.62532066 & 0.66845569 & 0.66074723 & 0.67446863 & 4 & 0.62563851 & 0.66881563 & 0.66111576 & 0.67483919 \\
\hline 14 & 0.62555932 & 0.66871951 & 0.66101985 & 0.67474217 & 3 & 0.62563848 & 0.66881566 & 0.66111565 & 0.67483923 \\
\hline 12 & 0.62562814 & 0.66880302 & 0.66110364 & 0.67482532 & 2 & 0.62563854 & 0.66881561 & 0.66111586 & 0.67483919 \\
\hline 10 & 0.62563737 & 0.66881433 & 0.66111437 & 0.67483735 & 1 & 0.62563843 & 0.66881586 & 0.66111592 & 0.67483946 \\
\hline 0 & 0.62563886 & 0.66881583 & 0.66111589 & 0.67483939 & 0 & 0.62563836 & 0.66881582 & 0.66111589 & 0.67483920 \\
\hline 0 & 0.62563878 & 0.66881593 & 0.66111572 & 0.67483913 & 0 & 0.62563841 & 0.66881591 & 0.66111581 & 0.67483919 \\
\hline 0 & 0.62563872 & 0.66881580 & 0.66111571 & 0.67483926 & 0 & 0.62563846 & 0.66881569 & 0.66111578 & 0.67483930 \\
\hline 10 & 0.62563703 & 0.66881444 & 0.66111416 & 0.67483761 & 0 & 0.62563843 & 0.66881570 & 0.66111577 & 0.67483935 \\
\hline 9 & 0.62563784 & 0.66881497 & 0.66111503 & 0.67483833 & 0 & 0.62563840 & 0.66881587 & 0.66111591 & 0.67483913 \\
\hline 8 & 0.62563799 & 0.66881528 & 0.66111545 & 0.67483868 & & & & & \\
\hline
\end{tabular}

${ }^{1}$ Resistance determinations made at 5 min intervals.

${ }^{2}$ Station: distance $(\mathrm{cm})$ thermometer raised above full immersion.

${ }^{3}$ All determinations made with normal measuring current. 
Table A3b. Immersion characteristics of thermometers in zinc cell, ${ }^{1,3}$

\begin{tabular}{|c|c|c|c|}
\hline \multirow{2}{*}{$\frac{\text { Station }^{2}}{\mathrm{~cm}}$} & \multicolumn{2}{|c|}{ Resistance of thermometer number } & \multirow[b]{2}{*}{8205} \\
\hline & 8202 & 8204 & \\
\hline 0 & 0.95931822 & 0.92788595 & 0.97041322 \\
\hline 0 & 0.95931846 & 0.92788611 & 0.97041326 \\
\hline D & 0.95931850 & 0.92788615 & 0.97041342 \\
\hline 0 & 0.95931844 & 0.92788625 & 0.97041309 \\
\hline 18 & 0.95818532 & 0.92679249 & 0.96920870 \\
\hline 18 & 0.95816807 & 0.92676693 & 0.96918238 \\
\hline 16 & 0.95884974 & 0.92745293 & 0.96990494 \\
\hline 14 & 0,95922028 & 0.92779867 & 0.97029903 \\
\hline 12 & 0.95930572 & 0.92787549 & 0.97039663 \\
\hline 10 & 0.95931639 & 0.92788322 & 0.97040958 \\
\hline 0 & 0.95931885 & 0.92788618 & $0.970413 \mathrm{E} \mathrm{I}$ \\
\hline 0 & 0.95931879 & 0.92788625 & 0.97041361 \\
\hline 0 & 0.95931866 & 0.92788612 & 0.97041344 \\
\hline 0 & 0.95931875 & 0.92788634 & 0.97041330 \\
\hline 10 & 0.95931649 & 0.92788339 & 0.97041009 \\
\hline 9 & 0.95931708 & 0.92788429 & 0.97041080 \\
\hline 8 & 0.95931786 & 0.92788468 & 0.97041149 \\
\hline 7 & 0.95931810 & 0.92788521 & 0.97041190 \\
\hline 6 & 0.95931812 & 0.92788541 & 0.97041214 \\
\hline 0 & 0.95931881 & 0.92788616 & 0.97041331 \\
\hline 0 & 0.95931876 & 0.92788638 & 0.97041326 \\
\hline 0 & 0.95931920 & 0.92788636 & 0.97041333 \\
\hline 0 & 0.95931870 & 0.92788626 & 0.97041335 \\
\hline 5 & 0.95931818 & 0.92788564 & 0.97041231 \\
\hline 4 & 0.95931882 & 0.92788588 & 0.97041266 \\
\hline 3 & 0.95931856 & 0.92788584 & 0.97041295 \\
\hline 2 & 0.95931876 & 0.92788607 & 0.97041311 \\
\hline 1 & 0.95931850 & 0.92788622 & 0.97041325 \\
\hline 0 & 0.95931916 & 0.92788619 & 0.97041332 \\
\hline 0 & 0.95931833 & 0.92788620 & 0.97041322 \\
\hline 0 & 0.95931903 & 0.92788607 & 0.97041312 \\
\hline 0 & 0.95931882 & 0.92788632 & 0.97041306 \\
\hline 0 & 0.95931895 & 0.92788615 & 0.97041351 \\
\hline
\end{tabular}

$1,2,3$ See footnotes of Table A.3a. 